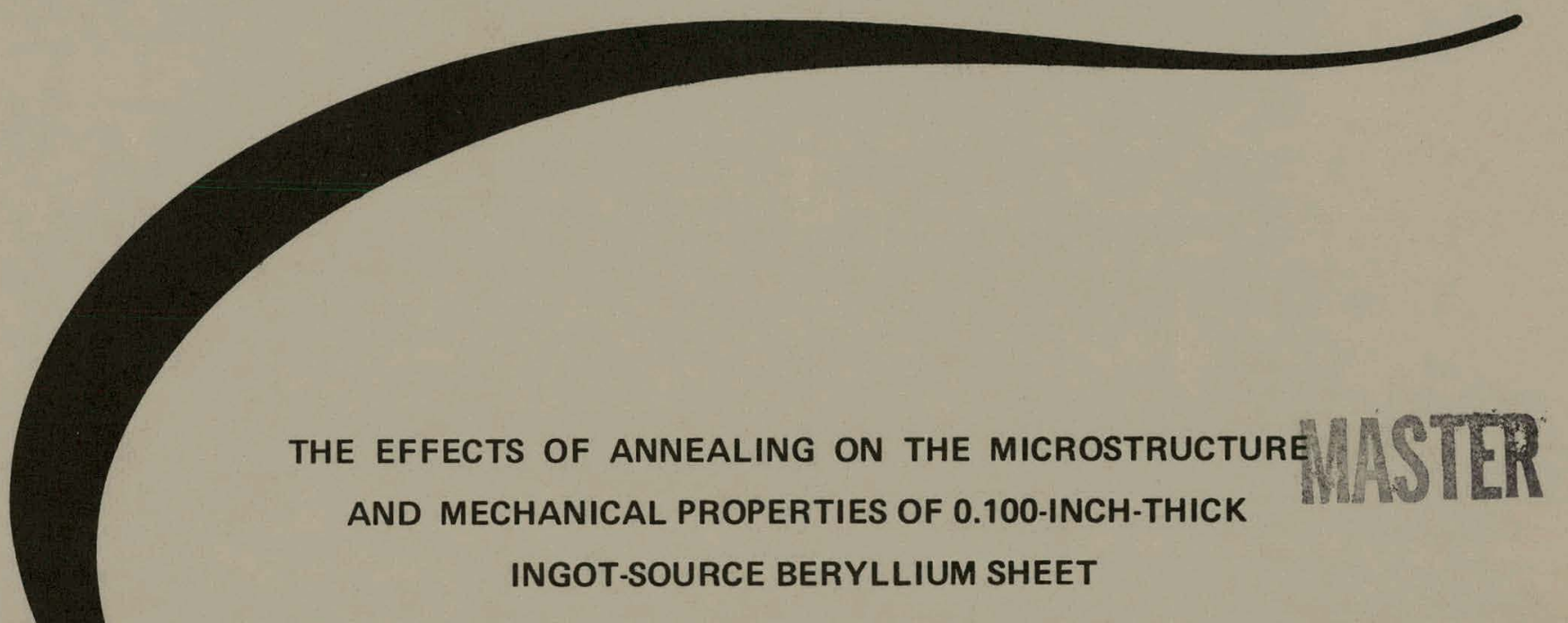

David L. Fergason

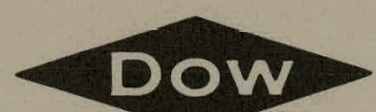

(1)

DOW CHEMICAL U.S.A. ROCKY FLATS DIVISION

P. O. BOX 888 GOLDEN, COLORADO 80401
THIS DOCUMENT CONFIRMED AS UNCLASSIFIED

DIVISION OF CLASSIFICATION

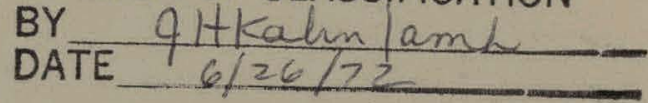

U. S. ATOMIC ENERGY COMMISSION CONTRACT AT(29-1)-1106 


\section{DISCLAIMER}

This report was prepared as an account of work sponsored by an agency of the United States Government. Neither the United States Government nor any agency Thereof, nor any of their employees, makes any warranty, express or implied, or assumes any legal liability or responsibility for the accuracy, completeness, or usefulness of any information, apparatus, product, or process disclosed, or represents that its use would not infringe privately owned rights. Reference herein to any specific commercial product, process, or service by trade name, trademark, manufacturer, or otherwise does not necessarily constitute or imply its endorsement, recommendation, or favoring by the United States Government or any agency thereof. The views and opinions of authors expressed herein do not necessarily state or reflect those of the United States Government or any agency thereof. 


\section{DISCLAIMER}

Portions of this document may be illegible in electronic image products. Images are produced from the best available original document. 


\section{LEGAL NOTICE}

This report was prepared as an account of work sponsored by the United States Government. Neither the United States nor the United States Atomic Energy Commission, nor any of their employees, nor any of their contractors, subcontractors, or their employees, makes any warranty, expressed or implied, or assumes any legal liability or responsibility for the accuracy, completeness or usefulness of any information, apparatus, product or process disclosed, or represents that its use would not infringe privately owned rights.

Printed in the United States of America

Available from the

National Technical Information Service

U. S. Department of Commerce

Springfield, Virginia 22151

Price: Printed Copy $\$ 3.00$ : Microfiche $\$ 0.65$ 


\title{
THE EFFECTS OF ANNEALING ON THE MICROSTRUCTURE AND MECHANICAL PROPERTIES OF 0.100-INCH-THICK \\ INGOT-SOURCE BERYLLIUM SHEET
}

\author{
David L. Fergason
}

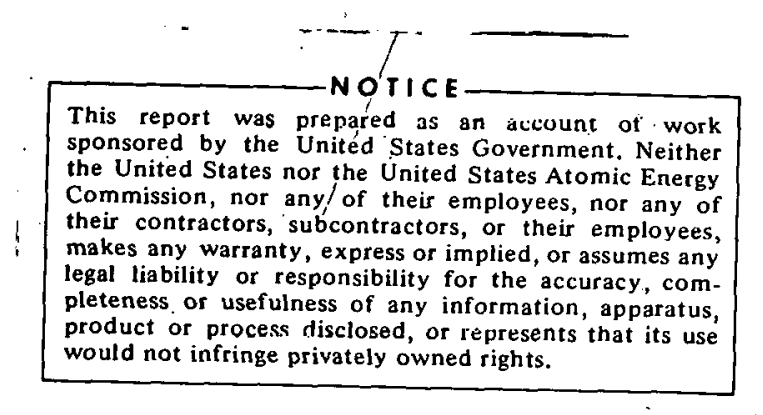

DOW CHEMICAL U.S.A. ROCKY FLATS DIVISION

P. O. BOX 888

GOLDEN, COLORADO 80401

Prepared under Contract AT(29-1)-1106
for the

Albuquerque Operations Office

U. S. Atomic Energy Commission 
RFP-1831. 


\section{CONTENTS}

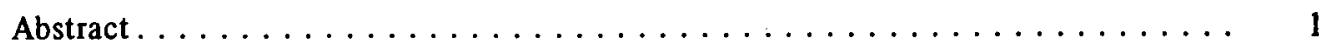

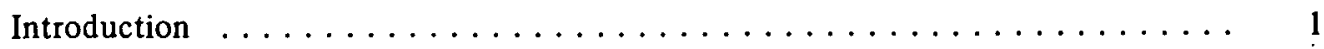

Effect of Heat Treatment on Impurity Distribution $\ldots \ldots \ldots \ldots \ldots \ldots \ldots$

Effect of Heat Treatment of Texture . . . . . . . . . . . . . . 2

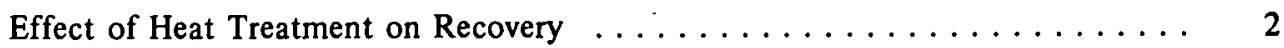

Effect of Grain Size: Recrystallization and Grain Growth........... 2

Heat Treatment and Mechanical Property Investigation . . . . . . . . . . 3

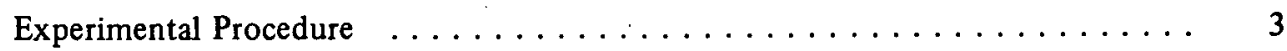

Results and Discussion ...................... 4

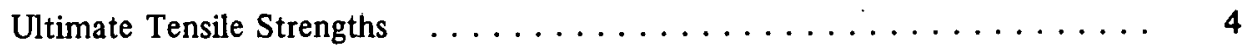

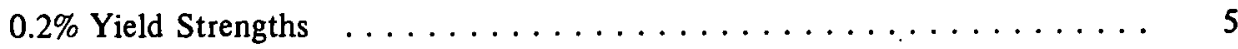

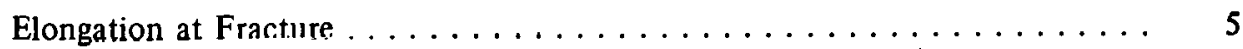

Statistical Calculations of $0.2 \%$ Yield Strength Data ........... s

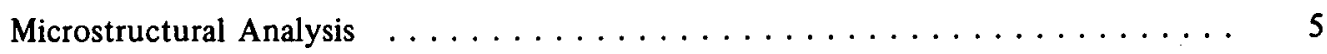

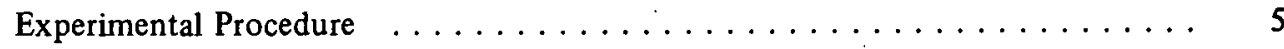

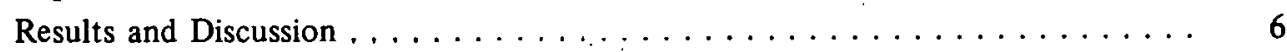

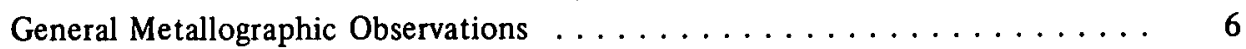

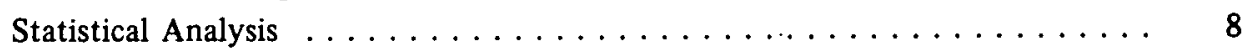

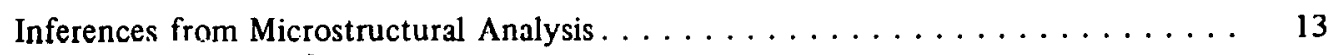

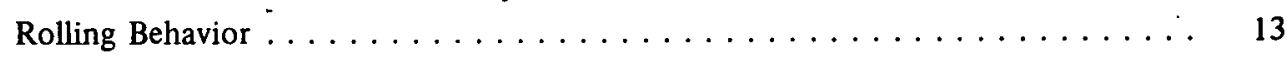

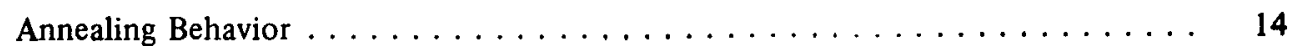

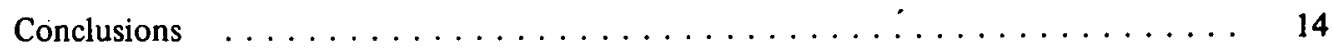

Heat Treatment and Mechanical Property Investigation . . . . . . . . 14

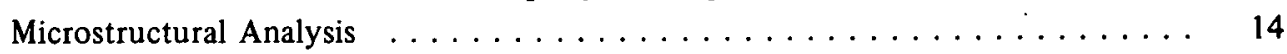

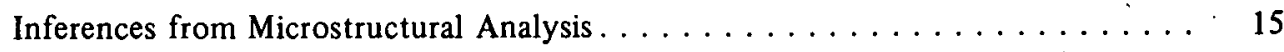

Recommendations ........................... 15

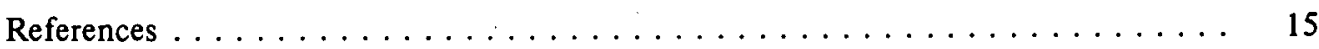

APPENDIX I. Room Temperature Tensile Data from Partially-Annealed Beryllium. . I-1

APPENDIX II. Statistical Calculations of

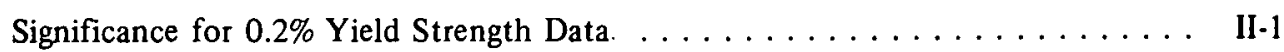

APPENDIX III. Summary of Metallographic

Grinding and Polishing Procedures (Reference 19) $\ldots \ldots \ldots \ldots \ldots \ldots$ III-1

APPENDIX IV. Sample of Grain-Measurement Data

A. As Rolled Microstructure - Area $1 \quad \ldots \ldots \ldots \ldots \ldots \ldots \ldots$ IV-1

APPENDIX V. Statistics from Computer Analyses of Grain $\Lambda$ rea Data . . . . . V V-1

APPENDIX VI. Grain Area Histogram and

Cumulative Frequency Distribution Data . . . . . . . . . . . . VI-1

APPENDIX VII. Loge (Grain Area) Histogram

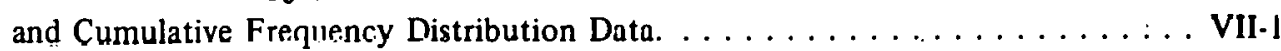




\section{ACKNOWLEDGMENTS}

The author gratefully acknowledges the help and encouragement of Professors M. T. Hepworth and C. S. Barrett during the course of this research. Appreciation is expressed to Dow Chemical. U.S.A., Rocky Flats Division, under contract to the Atomilc Energy Cunmission [AEC contraot $\Lambda \mathrm{T}(39-1)$. 1106]. This work formed the basis for a Master of Science in Metallurgy thesis and a company research project.

The author would also like to acknowledge the helpful comments and discussions of Dr. Clinton R. Heiple of Dow Chemical U.S.A., and Mr. J. K. Lynch formerly of Dow Chemical U.S.A.

Finally, the author is indebted to Mr. A. D. Mills and Mr. W. M. Leverett for their experimental assistance. 


\title{
THE EFFECTS OF ANNEALING ON THE MICROSTRUCTURE AND MECHANICAL PROPERTIES OF 0.100-INCH-THICK INGOT-SOURCE BERYLLIUM SHEET
}

\author{
David L. Fergason
}

\begin{abstract}
The effects of various annealing cycles on the microstructure and room temperature mechanical properties of a typical as-rolled, 0.100 -inch-thick, ingot-source beryllium sheet were investigated. Microstructures from heattreated material having various yield strengths were quantitatively analyzed. The data indicate that a direct correlation exists between the percent of the large, unrecrystallized grains in the characteristically duplexed microstructures and the $0.2 \%$ yield strength.* It is suggested that the large grains have an orientation relationship to the plane of the sheet; this could explain their anisotropic deformation and recrystallization characteristics.
\end{abstract}

\section{INTRODUCTION}

Historically the development of beryllium has resulted in two kinds of commercially available material: ingot source and powder source. In the ingot source process relatively sound castings are enclosed in steel and then forged and/or rolled directly into sheet. In the powder source process the ingots are machined into chips, and ground into powder which is then vacuum-hot pressed into blocks.

The power wrought products are, in general, characterized by relatively high impurity content ( 1 to $5 \% \mathrm{BeO})$, strengths of $\sim 55,000$ psi minimum yield and $\sim 70,000$ psi ultimate, ductility of $\sim 5 \%$, a fine grain size ( $15 \mu \mathrm{m}$ average) and a relatively high texturing tendency for a given reduction. ${ }^{1}$ Ingot-sheet products, on the other hand, are characterized by higher purity levels (less than $0.50 \%$ total impurities), lower strengths $(\sim 30,000$ psi yield and $\sim 45,000$ psi ultimate) higher ductility $(\sim 7 \%)$ and larger grain size (typically $40 \mu \mathrm{m}$ ). The lower impurity level and a lower texturing tendency are credited with the improved ductility in the thickness direction and the resulting improved formability of ingot versus powder metallurgy sheet. In view of the brittle history of beryllium it is not surprising that wrought ingot source products are used almost exclusively in the fully annealed condition to capitalize on ductility and formability. In contrast, powder products are rarely used in the fully annealed condition since optimum combinations of properties are achieved with partial anneals.

Annealing to achieve optimum formability with the ingot source product resulted in its being characterized by lower strength - a natural consequence of the fully annealed

\footnotetext{
*The yield strength decreases linearly as the percentage of recrystallized microstructure increases.
}

condition. Therefore it has been less attractive from a strength-to-weight structural standpoint. Most beryllium products today are of powder origin.

In view of these considerations a major objective of this study was to investigate the effects of partial annealing treatments on the room temperature mechanical properties . of ingot-source beryllium sheet. Specifically, this work was undertaken to determine what strength combinations could be achieved while maintaining a reasonable level of ductility.

Another major objective was to perform a quantitative microstructural analysis to determine whether a correlation between mechanical properties and microstructure could be observed for partially annealed wrought ingot beryllium sheet.

Before attempting to correlate mechanical properties with a microstructural phenomena it was first necessary to review the variables which control the mechanical properties of beryllium. These variables include the amount and kinds of impurities, the distribution of impurities, the grain size, the texture, the thermo-mechanical history, the amount of residual work, and the amount of surface damage from machining operations.

By limiting this study to a single beryllium sheet randomly selected from production material it was assured ${ }^{2}$ that the starting material was uniform in chemistry (both in level, kinds, and distribution of impurities), microstructure, and texture; and that the material was representative of the production process. Partial annealing heat treatments could not be expected to change the level or kinds of impurities, and the surface damage effects could also be dismissed by following established industrial machining and chemical milling practices in the preparation of tensile bars.

The four remaining variables: grain size, texture, the amount of residual work, and impurity distribution, could be expected to change with heat treatment and affect the mechanical properties. The results of a literature survey follows:

\section{Effect of Heat Treatment on Impurity Distribution}

A number of investigators ${ }^{3-7}$ have observed a solutionizingaging reaction between $\mathrm{Fe}$ and $\mathrm{Al}$ in beryllium. Carrabine et al., ${ }^{4}$ have reported the influence of the $\mathrm{Fe}-\mathrm{Al}$ interaction on the mechanical properties of powder source beryllium. 
Although powder source beryllium contains higher $\mathrm{BeO}$ content than ingot source material the remaining impurity levels, especially iron and aluminum, are similar. (Powder source scrap is used as feed for the ingot process.) Therefore a similar influence on ingot sheet properties can be expected.

Fraikor et al., ${ }^{3}$ reviewed the literature on the $\mathrm{Fe}-\mathrm{Al}$ precipitation reaction work and characterized the Dow Rocky Flats ingot source beryllium production sheet using electron microscopy and microprobe analyses. Their proposed precipitation reaction is summarized as follows:

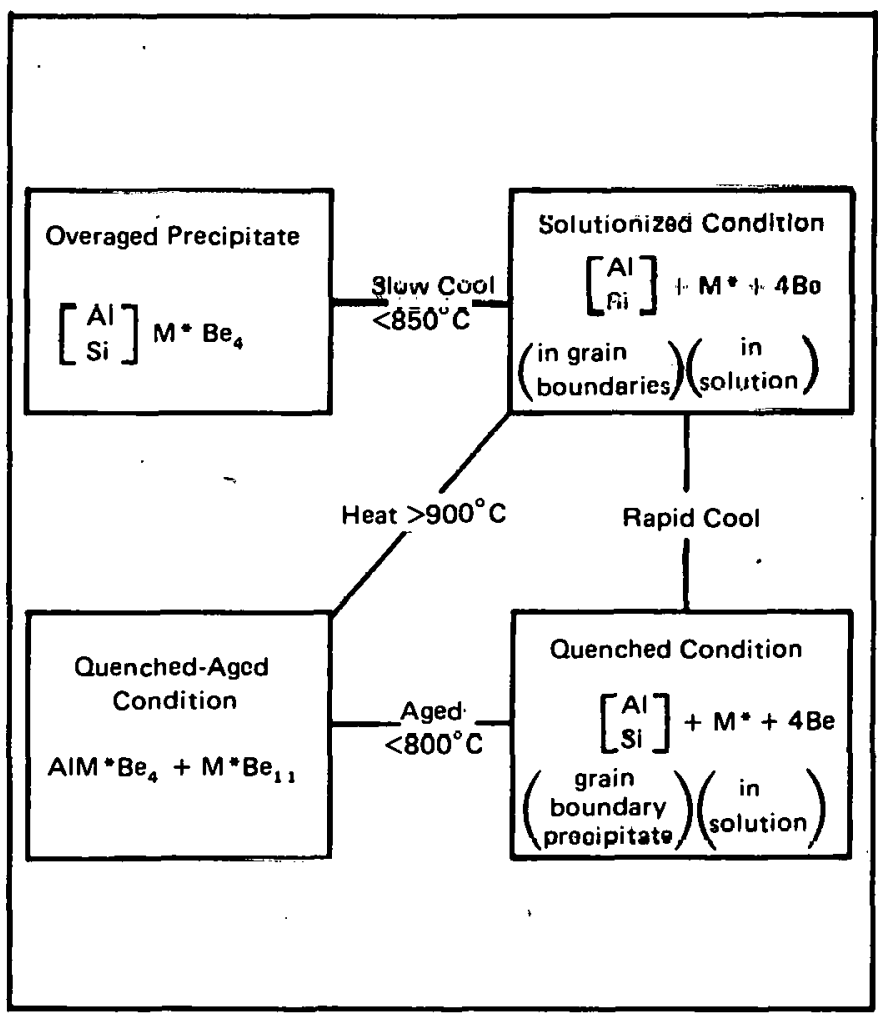

${ }^{*} \mathrm{M}=$ transition element such as $\mathrm{Fe}, \mathrm{Cr}, \mathrm{Mn}$, or $\mathrm{Ni}$.

Since the material used in this study was rolled to $780^{\circ} \mathrm{C}$ and air cooled to room temperature (a slow cool according to Fraikor ${ }^{8}$ ) the reaction predicts only $\mathrm{AlMBe}_{4}$ precipitates to be present in the as-rolled condition. Since the approximate threshold temperature for excessive grain growth in ingot sheet is $800^{\circ} \mathrm{C}$, all partial annealing treatments of this study were conducted at lower temperatures. The reaction predicts no change in the $\mathrm{AlMBe}_{4}$ equilibrium for these heat treatments. Fraikor et al., ${ }^{3}$ reported no change in impurity distribution after 20 hours at $780^{\circ} \mathrm{C}$.

It was concluded that the partial annealing cycles used in this study did not change the impurity distributions. Therefore, no change in room temperature mechanical properties should be expected from this effect, since the study was limited to a single production sheet. However, if samples of material had been used having different $\mathrm{Fe} / \mathrm{Al}$ ratios, an effect on mechanical properties could have been expected.

\section{Effect of Heat Treatment on Texture}

Several invesgigators ${ }^{9-12}$-have reported the texture behavior of ingot source beryllium sheet as influenced by heat treatment. In general, they found that the as-rolled texture of beryllium sheet was insensitive to heat treatment unless extensive grain growth occurred.

Since the times and temperatures selected for this study were not sufficient to cause extensive grain growth, it is assumed that the texture remained constant and did not bias the changes in mechanical properties caused by the partial anneals.

\section{Effect of Heat Treatment on Recovery}

G. L. Tuer et al., ${ }^{13}$ reviewed the literature on recrystallization studies and presented $x$-ray line broadening evidence of recovery phenomena for powder and ingot source beryl. lium. Significant findings of their studies include the following:

- Recovery processes are essentially complete after relatively short times at temperatures that are considerably below the recrystallization temperature.

- The kinetic behavior of recovery is essentially independent of nucleation and growth processes. In boryllium the recovery process appeared to he complete before definite metallographic evidence of the recrystallization became apparent.

- Recovery and recrystallization pirocesses have a close relationship to the modes of deformation which have operated in prior straining.

Of specific interest was their data which showed recovery processes to be approximately $95 \%$ complete af ter onc hour at $650^{\circ} \mathrm{C}$. The partial annealing cycles used in this study consisted of time and/or temperature combinations which would cause essentially complete recovery, except for samples tested in the as-rolled condition. In this study it was therefore concluded that the effects of recovery on the room temperature mechanical properties were essentially constant.

\section{Effect of Grain Size: Recrystallization and Grain Growth}

The influence of grain size on the mechanical properties of beryllium is well established for fully annealed material: 
the metal follows a Hall-Petch-type relationship. ${ }^{14,15}$ Since various strain states were intentionally induced in the following partial annealing characterization study, the material strain conditions were not constant and a HallPetch relationship was not expected.

The variation in grain size as the result of recrystallization and grain growth effects can be observed using light microscopy. Therefore optical microscopy was used to perform a quantitative analysis of the microstructure with confidence that the other variables of texture, impurity distribution, and recovery did not influence any correlation observed with mechanical properties.

\section{HEAT TREATMENT AND MECHANICAL PROPERTY INVESTIGATION}

\section{Experimental Procedure}

The 0.100-inch-thick, cross-rolled, ingot source material characterized in this study was randomly selected from the normal production stream with the exception that the material was not annealed after the last rolling pass. A summary of the fabrication history of the sheet selected is given in Table 1. A chemical analysis from samples of this material is listed in Table 2. The chemistry typical of the production material.

Tensile cuupon locations were stenciled on the 0.102 -inch by 17 -inch by 52 -inch sheet. The 1 - by 4 -inch coupons were removed from the sheet by band sawing and subsequently machined into tensile specimens using tracer-controlled side milling. Cuts of 0.015 inch were used in roughing, and finishing was done with successive passes of $0.010,0.005$, and 0.003 inch to minimize the amount and depth of surface damage in each specimen. All machining was done under cutting oil and is typical of Rocky Flats Division practice. The specifications for these flat tensile specimens are shown in Figure 1.

After machining, each specimen was chemically milled 0.003 to 0.004 inch per surface to remove the surface damage induced by the machining operation. The chemical milling also served as a quality control to detect latent surface defects which might have been caused by improper machining practices. Chemical milling was accomplished with a $20 \% \mathrm{HNO}_{3}, 1 \% \mathrm{HF}$ by volume, aqueous solution at room temperature.

Following the chemical milling, sets of three specimens were heat treated in a resistance-type vacuum tube furnace
Table 1. Thermal-Mechanical History of 0.100-Inch-Thick IngotSource Beryllium Sheet.*

Material: Vacuum-induction cast beryllium. Feed source is recycle ingot sheet scrap and/or S-200 type Powder scrap. Individual billet sizes are normally 9 inches square by 3.5 inches thick.

Can Material: Type 304 stainless steel (5/8-inch thick) assembled by electron beam welding and soaked 8 to 10 hours at $1040^{\circ} \pm 15^{\circ} \mathrm{C}$.

A. Can Rolling Schedule:

\begin{tabular}{|c|c|c|c|}
\hline $\begin{array}{c}\text { Beryllium Thickness"* } \\
\text { Range (inch) }\end{array}$ & $\begin{array}{l}\text { Reduction } \\
\text { Per Pass } \\
\text { (inch) }\end{array}$ & $\begin{array}{l}\text { Temperature } \\
\left({ }^{\circ} \mathrm{C} \pm 15^{\circ} \mathrm{C}\right)\end{array}$ & Remarks \\
\hline $3.5 \rightarrow 2.2$ & 0.215 & 1040 & $\begin{array}{l}\text { Rotate } 90^{\circ} \\
\text { Between Passes }\end{array}$ \\
\hline $\begin{array}{l}\text { Reheat } 25 \text { minutes } \\
2.2 \rightarrow 1.14\end{array}$ & 0.200 & $\begin{array}{l}980 \\
980\end{array}$ & $\begin{array}{l}\text { Rotate } 90^{\circ} \\
\text { Between Passes }\end{array}$ \\
\hline $\begin{array}{l}\text { Reheat } 25 \text { minutes } \\
1.14 \rightarrow 0.81\end{array}$ & 0.150 & $\begin{array}{l}870 \\
870\end{array}$ & $\begin{array}{l}\text { Rotate } 90^{\circ} \\
\text { Between Passes }\end{array}$ \\
\hline $\begin{array}{l}\text { Reheat } 15 \text { minutes } \\
0.81 \rightarrow 0.55\end{array}$ & 0.130 & $\begin{array}{l}870 \\
870\end{array}$ & $\begin{array}{l}\text { Rotate } 90^{\circ} \\
\text { Retween Passes }\end{array}$ \\
\hline $\begin{array}{l}\text { Reheat } 15 \text { minutes } \\
0.55 \rightarrow 0.35\end{array}$ & 0.100 & $\begin{array}{l}870 \\
870\end{array}$ & $\begin{array}{l}\text { Unidirectionally } \\
\text { Roll }\end{array}$ \\
\hline $\begin{array}{l}\text { Reheat } 15 \text { minutes } \\
0.35 \rightarrow 0.250\end{array}$ & 0.065 & $\begin{array}{l}780 \\
780\end{array}$ & $\begin{array}{l}\text { Unidirectionally } \\
\text { Roll }\end{array}$ \\
\hline Reheat 20 hours & & 780 & \\
\hline $\begin{array}{l}\text { Shear and Remove } \\
\text { Stainless Steel }\end{array}$ & & $\begin{array}{l}500- \\
700\end{array}$ & See Note*** \\
\hline \multirow[t]{2}{*}{$0.240 \rightarrow 0.100$} & $10 \%$ & 780 & $\begin{array}{l}\text { Unidirectionally } \\
\text { roll at } 90^{\circ} \text { to } \\
\text { last can rolling } \\
\text { direction }\end{array}$ \\
\hline & & & $\begin{array}{l}\text { Reheats are } \\
5-10 \text { minutes } \\
\text { between passes } \\
\text { except for a one } \\
\text { hour soak be- } \\
\text { tween the fourth } \\
\text { and fifth passes }\end{array}$ \\
\hline
\end{tabular}

"Taken from "Ingot Sheet Beryllium Fabrication" by J. L. Frankeny and D. R. Floyd, RFP-910, Rocky Flats Division, Dow Chemical U.S.A., February 9, 1968.

* Note that the dimensions refer to the beryllium thickness, not to to the total can thickness.

**After the sheet has been annealed and decanned it is pickled in a $2 \% \mathrm{HF}, 48 \% \mathrm{HNO}_{3}$, aqueous solution at room tem perature to remove surface contaminates. Approximately 0.005 inch per surface is removed.

which had been preheated to temperature. The three specimens were positioned in the center of the three-inchdiamcter by 10-inch-long heating zone and the furnace temperature was monitored with both the furnace control thermocouple and with a separate thermocouple attached to a potentiometer. The maximum time required to recover the preset furnace temperature after the samples had becn placed was 5 mintues. This time includes an initial 30-second purge with argon just prior to evacuation. After each annealing cycle the furnace was back-filled with argon and the specimens were removed and air cooled to to room temperature. 
Table 2. Chemical Analysis of 0.100-Inch-Thick Ingot-Source Beryllium Sheet.

\begin{tabular}{lc}
\multicolumn{1}{c}{ Impurity } & Analysis (wt \%) \\
\cline { 2 - 2 } Beryllium & $99: 37$ \\
Aluminum & 0.073 \\
Carbon* & .053 \\
Calcium & .003 \\
Cadmium & .001 \\
Cobalt: & .001 \\
Chromium & .013 \\
Cóppet & .008 \\
Iron* & .151 \\
Magnesium & .003 \\
Manganese & .012 \\
Molybdenum & .003 \\
Oxygen** & .005 \\
Nitrogen & .007 \\
Nickel & .025 \\
Lead & .001 \\
Silicon & .040 \\
Titanium & .015 \\
Tungsten & .020 \\
7ine & .010
\end{tabular}

"Chemical analysis; all others by spectroscopic analysis.

**Neutron activation analysis of 0.100 -inch-thick ingot-source beryllium sheet.

Before the heat-treated tensile specimens were tested, each specimen was again chemically milled 0.003 to 0.004 inch per surface as a pickling treatment and as a precautionary measure to ensure that all residual surface damage effects had been removed.

The problems associated with the effects of machine damage have been reported by Beitscher ${ }^{16}$ for ingot-source beryllium and by Ward et al., ${ }^{17}$ and Mathews et al., ${ }^{18}$ for powder source beryllium. The above sample preparation technique is typical of industry practices with the exception that ordinarily the tensile specimens are machined from annealed material and only etched 0.004 to 0.005 inches per surface to remove machine damage. In this study all samples were double-etched a total of 0.008 -inch minimum per surface as describcd above.

The heat-treated specimens were tensile tested on an Instron machine using a crosshead speed of $0.005 \mathrm{in} . / \mathrm{min}$. which corresponds to a strain rate of $0.005 \mathrm{in} . / \mathrm{in} . / \mathrm{min}$.

\section{Results and Discussion}

The room temperature tensile properties from the heat treatment study are listed in Appendix I and the mean values are shown in Table 3 . The dala iriclude $95 \%$ confidence limits.

The heat treatment study was performed primarily on longitudinal tensile bars (tensile axis parallel to the last rolling direction); although a few transverse properties were

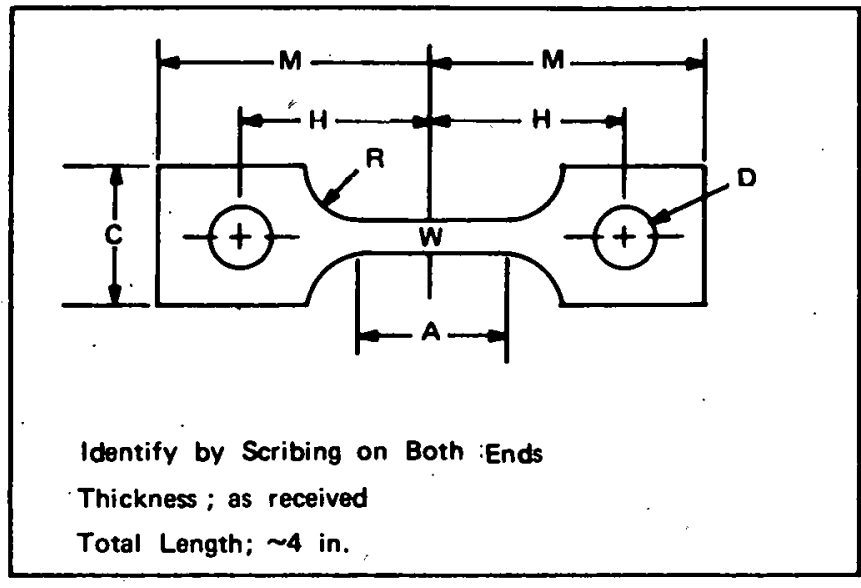

\begin{tabular}{|c|c|}
\hline Legend & . \\
\hline $\begin{array}{l}A \text { - Gage length } \\
M \text { - One.half total length }\end{array}$ & $\begin{array}{l}1.125 \pm 0.005 \text { in. } \\
2.000 \pm 0.020 \text { in. }\end{array}$ \\
\hline C - Width of grip section & $\begin{array}{l}0.85010 .005 \text { in. } \\
\text { (note increased } \\
\text { width) }\end{array}$ \\
\hline $\begin{array}{l}W \text { - Width of gage section } \\
\mathbf{R} \text { - Radius of fillet }\end{array}$ & $\begin{array}{l}0.200 \pm 0.002 \text { in. } \\
0.5 \text { in. nominal }\end{array}$ \\
\hline $\begin{array}{l}\text { H - Distance from center of gage length } \\
\text { to center of hole }\end{array}$ & $1.400 \pm 0.005 \mathrm{in}$. \\
\hline D - Diameter of holes & fit for $3 / 8$-in. pin \\
\hline
\end{tabular}

Notes: The ends of the reduced section shall not differ in width by more than 0.002 inch. There shall be a gradual taper in width from the ends to the center of from 0.002 to 0.002 inch. It is imperative that there be no undercutting of the width at the fillet radii.

The specimen shall be symmetrlual about its longitudinal axis to within 0.001 inch.

The surfaces of the reduced section shall be finished to at least $32 \mathrm{rms}$. The surfaces of the grip section shall be at least 63 root-mean-square. All obvious scratches or nicks that are in the reduced section and are transverse to the longitudinal axis shall be removed.

Figure 1. Pin-Grip Sheet:Type Tensile Specificetions.

determined for comparison in the as-rolled and most fully annealed $\left(760^{\circ} \mathrm{C} / 24\right.$ hours $)$ conditions. The data show that the $760^{\circ} \mathrm{C} / 24$ hours anneal caused nearly identical responses in the two directions and the transverse/longitudinal property ratios remained approximately constant: $0.2 \%$ yield strengths, 0.98; ultimate strengths, 0.9 ; and elongations, 0.67 . Therefore the main heat treatment study was performed un lungitudinal tensiles; and it was assumed that after partial annealing treatments the transverse properties would exhibit the same response as the longitudinal properties.

\section{ULTIMATE TENSILE STRENGTHS}

The longitudinal ultimate tensile strengths shown in Table 3, were fairly insensitive to the various time/ temperature combinations. All mean ultimate tensile 
Table 3. Tensile Properties of Partially Annealed 0.100-Inch-Thick Beryllium Sheet.

\begin{tabular}{|c|c|c|c|}
\hline $\begin{array}{l}\text { Heat Treatment } \\
\left({ }^{\circ} \mathrm{C}\right)\end{array}$ & $\begin{array}{c}0.2 \% \text { Yield } \\
\text { Strength (ksi) }\end{array}$ & $\begin{array}{l}\text { Ultimate Tensile } \\
\text { Strength (ksi) }\end{array}$ & $\begin{array}{c}\text { Elongation } \\
(\%) \\
\end{array}$ \\
\hline As-rolled T & $50.3 \pm 0.88$ & $57.2 \pm 4.0$ & $1.1 \pm 0.70$ \\
\hline As-rolled L & $51.1 \pm 1.2$ & $62.3 \pm 1.4$ & $2.0 \pm 0.93$ \\
\hline $760 / 24 \mathrm{hr} \mathrm{T}$ & $30.7 \pm 3.0$ & $51.5 \pm 4.4$ & $3.9 \pm 1.3$ \\
\hline $760 / 24 \mathrm{hr} \mathrm{L}$ & $31.2 \pm 3.5$ & $58.0 \pm 3.5$ & $5.5 \pm 0.46$ \\
\hline $650 / 2 \mathrm{hr} \mathrm{L}$ & $46.1 \pm 3.6$ & $62.0 \pm 3.6$ & $3.6 \pm 2.7$ \\
\hline $4 \mathrm{hr} \mathrm{L}$ & $45.8 \pm 0.53$ & $61.6 \pm 0.76$ & $3.5 \pm 0.80$ \\
\hline $6 \mathrm{hrL}$ & $46.3 \pm 0.30$ & $59.1 \pm 2.3$ & $2.4 \pm 0.76$ \\
\hline $675 / 2 \mathrm{hr} \mathrm{L}$ & $43.1 \pm 7.6$ & $58.1 \pm 9.0$ & $3.2 \pm 1.8$ \\
\hline $4 \mathrm{hr} \mathrm{L}$ & $42.2 \pm 8.4$ & $58.9 \pm 15.5$ & $3.7 \pm 1.9$ \\
\hline $700 / 2 \mathrm{hr} \mathrm{L}^{*}$ & $42.4 \pm 0.63$ & $59.8 \pm 1.1$ & $3.9 \pm 0.75$ \\
\hline $4 \mathrm{hr} \mathrm{L}$ & $41.4 \pm 2.5$ & $60.4 \pm 5.1$ & $4.3 \pm 3.0$ \\
\hline $725 / 2 \mathrm{hr} \mathrm{L}$ & $40.1 \pm 0.80$ & $60.7 \pm 3.6$ & $4.4 \pm 2.2$ \\
\hline $4 \mathrm{hr} \mathrm{L}$ & $40.9 \pm 2.1$ & $61.3 \pm 3.5$ & $4.7+1.7$ \\
\hline $760 / 1 \mathrm{hr} \mathrm{L}$ & $39.7 \pm 2.3$ & $59.6 \pm 7.2$ & $3.9 \pm 1.7$ \\
\hline $2 \mathrm{hr} \mathrm{L}$ & $36.0 \pm 1.4$ & $59.2 \pm 6.2$ & $4.9 \pm 2.4$ \\
\hline $6 \mathrm{hr} \mathrm{L}$ & $32.4 \pm 0.63$ & $58.4 \pm 6.1$ & $4.9 \pm 2.7$ \\
\hline $24 \mathrm{hr} \mathrm{L}$ & $31.2 \pm 3.5$ & $58.0 \pm 3.5$ & $5.5 \pm 0.46$ \\
\hline $775 / 15 \mathrm{~min} L$ & $37.1 \pm 1.7$ & $60.8 \pm 1.3$ & $5.4 \pm 0.57$ \\
\hline $30 \min \mathrm{L}$ & $34.9 \pm 0.92$ & $58.2 \pm 4.2$ & $5.4 \pm 1.2$ \\
\hline $1 \mathrm{hr} \mathrm{L}$ & $36.5 \pm 3.3$ & $59.2 \pm 7.0$ & $4.9 \pm 2.2$ \\
\hline
\end{tabular}

The data represent averages of three tests except where indicated, and includes $95 \%$ confidence limits.

*Average of two specimens.

strengths remained between a high of $62.3 \mathrm{ksi}$ (as rolled) and a low of $58.0 \mathrm{ksi}\left(760^{\circ} \mathrm{C} / 24 \mathrm{hr}\right)$. No significant trends were observed in the $95 \%$ confidence limits.

\section{$0.2 \%$ YIELD STRENGTHS}

The $0.2 \%$ yield strength data indicate that the higher heattreatment temperatures were more effective in lowering the yield strength than longer times at lower temperatures. The $0.2 \%$ yield strength was lowered approximately $20 \mathrm{ksi}$; that is, from $51.1 \mathrm{ksi}$ (as rolled) to $31.2 \mathrm{ksi}$ ( 24 hours at $760^{\circ} \mathrm{C}$ ). The $95 \%$ confidence limits did not indicate any significant trends between the lesser and more fully annealed tensiles; which indicates that no loss in reproducibility of results (or increase in data scatter) was observed in the less-annealed conditions.

\section{ELONGATION AT FRACTURE}

A comparison of the elongation data indicates an expected behavior: the elongations increase as the spread between the ultimate strength and the yield strength increases. With the ultimate strength remaining fairly constant throughout this study and the effects of increased annealing being shown by the lowering of the yield strength, the elongations increased from $1.1 \%$ (as rolled) to $5.5 \%$ (after 24 hours at $760^{\circ} \mathrm{C}$ ). Again, no trends were seen in comparisons of the $95 \%$ confidence limits.
Five different yield strength conditions were selected from the mechanical property data for a statistical microstructural analysis. The selected yield strengths and corresponding heat treatments are listed in Table 4.

Table 4. Selected Yield Strengths for Microstructural Analysis.

\begin{tabular}{|c|c|}
\hline Heat-Treatment Condition & $0.2 \%$ Yield Strength (ksi) \\
\hline As Rolled & $51.1 \pm 1.2$ \\
\hline $650^{\circ} \mathrm{C} / 4$ Hours & $45.8 \pm 0.53$ \\
\hline $700^{\circ} \mathrm{C} / 2$ Hours & $42.4 \pm 0.63$ \\
\hline $775^{\circ} \mathrm{C} / 1$ Hour & $36.5 \pm 3.3$ \\
\hline $760^{\circ} \mathrm{C} / 6$ Hours & $32.4 \pm 0.63$ \\
\hline
\end{tabular}

\section{STATISTICAL CALCULATIONS OF $0.2 \%$ YIELD STRENGTH DATA}

A statistical comparison of $0.2 \%$ yield strength from the five selected heat treatments using the students " $t$ " test indicated a minimum confidence level of $99 \%$ that the differences in means were real. A comparison of variances also showed a $99 \%$ confidence level that the variability in the five sets of data was the same. The results of the students " $t$ " tests and the "F" tests for variance are listed in Appendix II.

\section{MICROSTRUCTURAL ANALYSIS}

\section{Experimental Procedure}

Microstructural samples were prepared from one end of a tested tensile bar representative of each of the five selected heat-treatment conditions. The location of these metallographic samples is illustrated in Figure 2. A comparison

Figure 2. Sketch of Microstructural Sample Location.

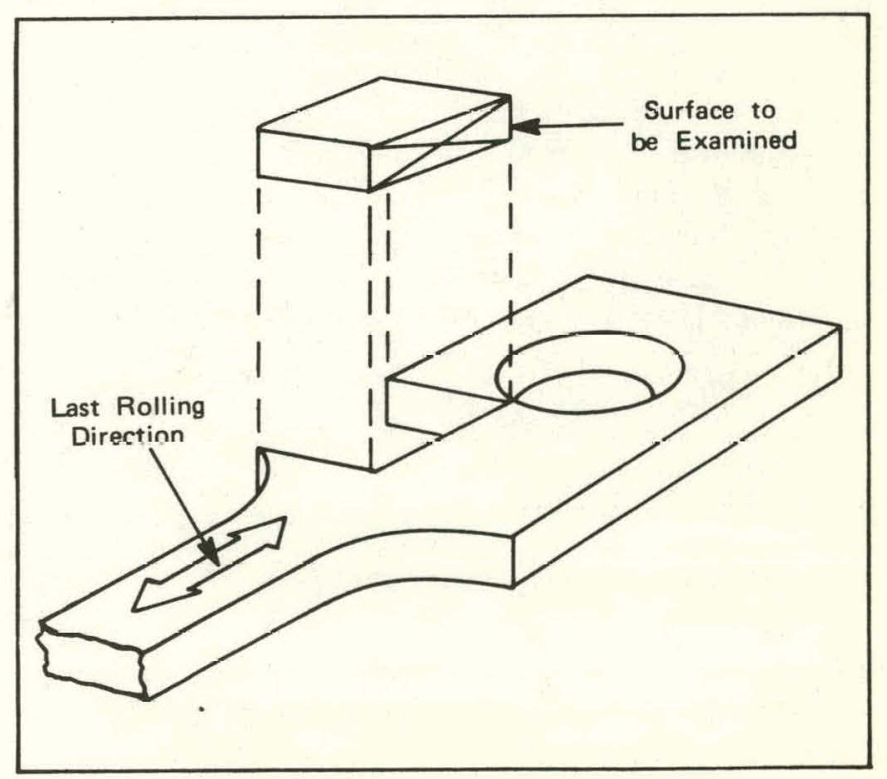


between samples taken from tested and untested tensile bars was made to determine whether tensile testing disturbed the microstructure. No evidence of pinhole distortion or adjacent microstructural disturbance was observed.

The metallographic samples were machined from the tensile bar ends and mounted in a suitable mounting material. Rough grinding and final polishing procedures are discussed in detail in Reference 19, and summarized in Appendix III. Sample preparation required considerable skill to obtain quality photomicrographs which are suitable for statistical analyses. This was particularly true when preparing samples of the more fully worked structures containing sub-or-tilt boundaries which were difficult to distinguish from lowangle grain boundaries.

After the samples had been prepared, three or four representative areas were photographed at $100 \mathrm{X}$ from each of the five selected samples. Negatives of these areas were used to make $2 \mathrm{X}$ prints (200X total magnification) measuring approximately 8 by 10 inches. In this manner, relatively large areas of the samples could be examined at a magnification fication sufficient to resolve the finer structural details.

The determination of grain-size distribution was accomplished by measuring individual grains from each microstructure. Since the microstructures contained both nonuniform structures and nonequiaxed grains, an individual grain area measurement was used based upon the overall grain length and a visually estimated average grain width. Approximately 400 to 600 grains were measured from three or four representative areas of each microstructure.

The length and width data were converted to grain area data and, with the aid of a computer, to $\log _{e}$ (Grain Area) data. A sample of the data is listed in Appendix IV. A computer program was also used to calculate the arithmetic means and standard deviations, and average grain length-towidth ratio $(\mathrm{L} / \mathrm{W})$ for each area of each of the five material conditions. These data are listed in Appendix V.

\section{Results and Discussion}

\section{GENERAL METALLOGRAPHIC OBSERVATIONS}

Representative microstructures from the five selected heat treatments are shown in Figures 3, 4, 5, 6, and 7, in order of decreasing yield strengths.

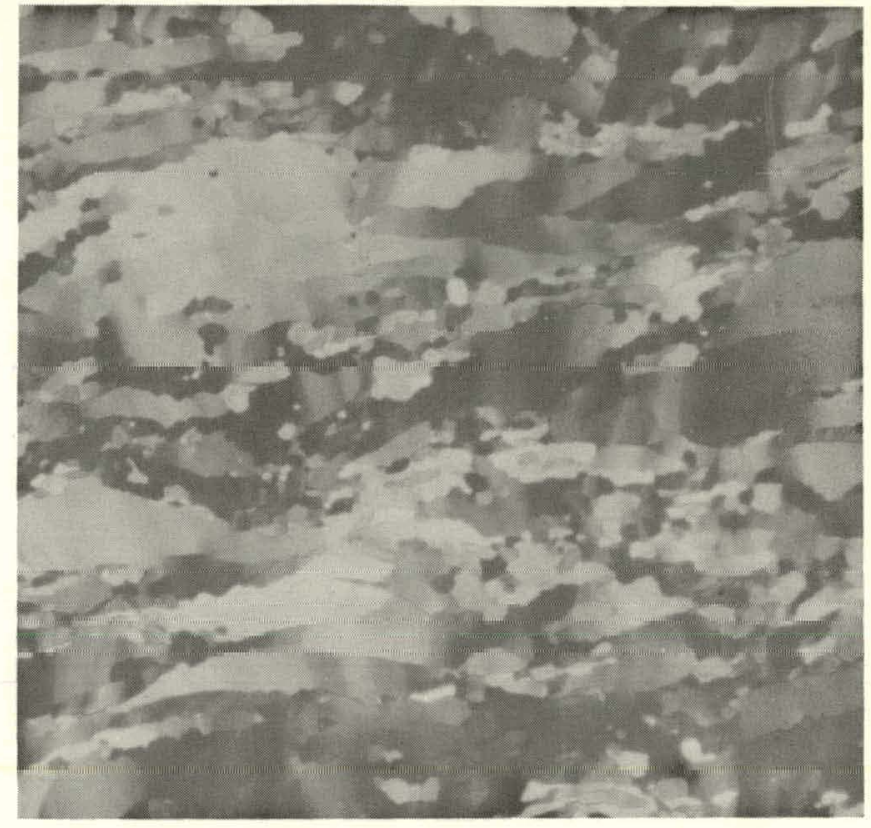

Figure 3. As-Rolled Microstructure.

Figure 4. Partially Annealed Microstructure, $650^{\circ} \mathrm{C} / 4$ Hours.

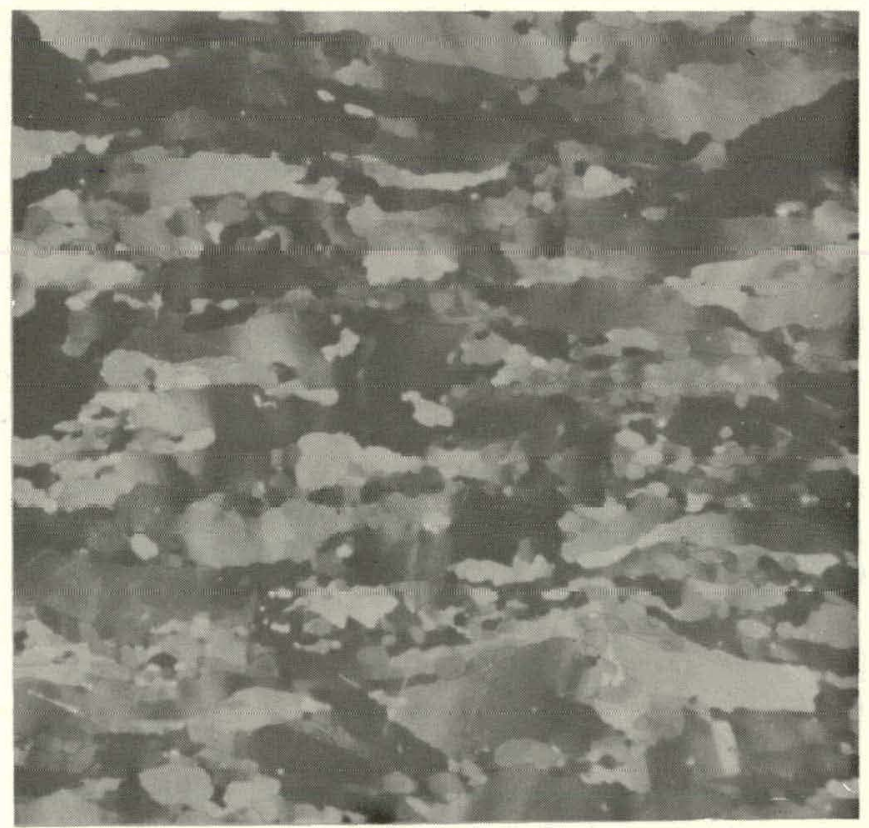




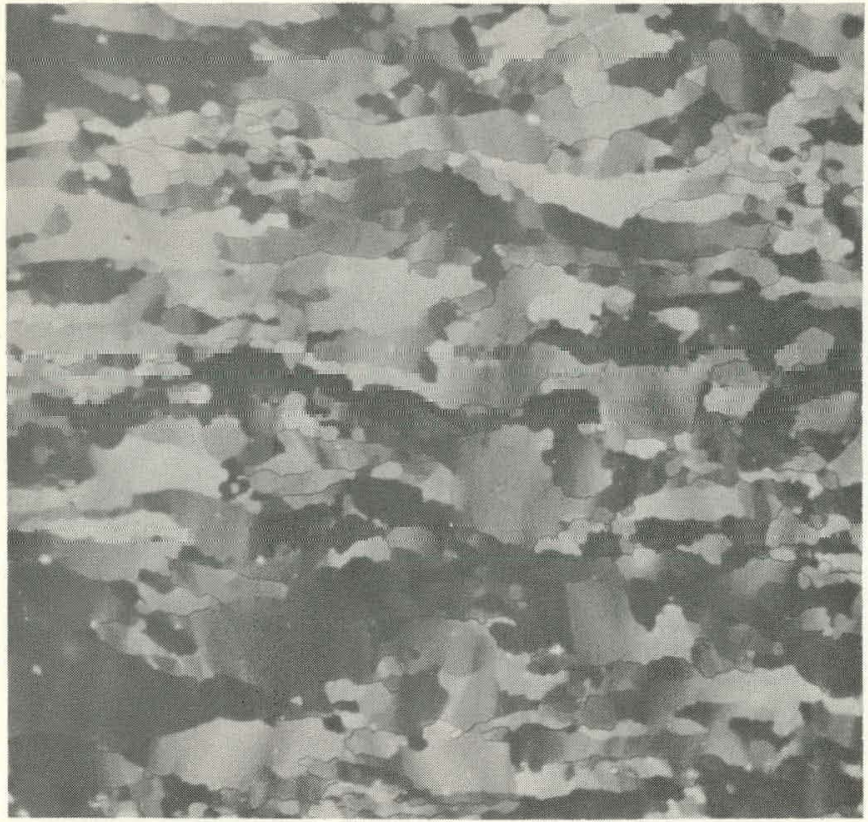

Figure 5. Partially Annealed Microstructure, $700^{\circ} \mathrm{C} / 2$ Hours.

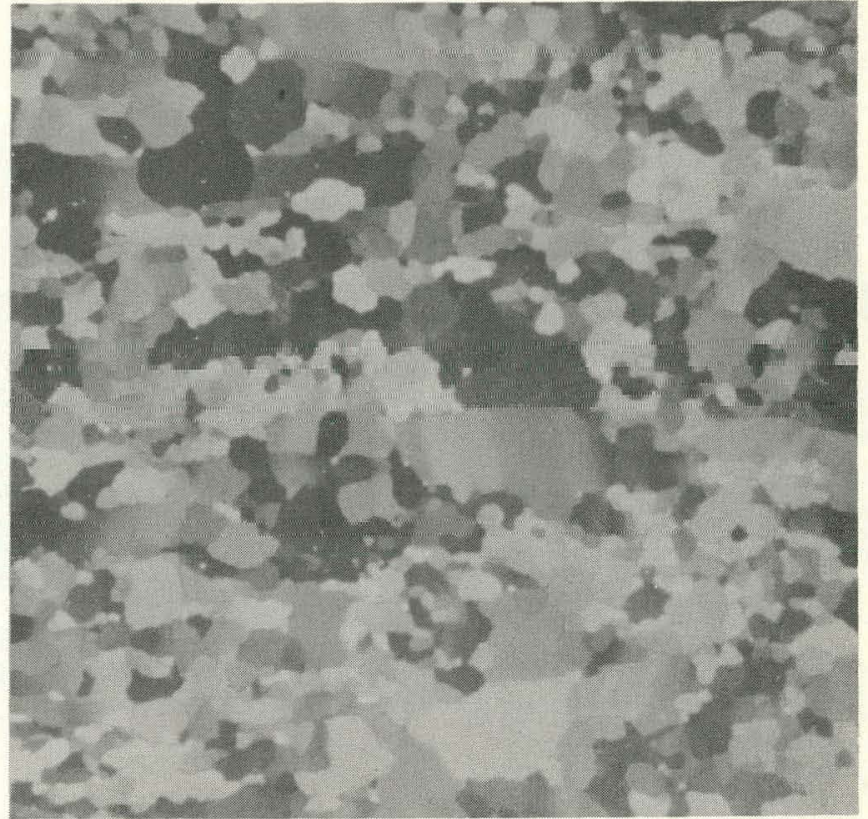

Figure 7. Partially Annealed Microstructure, $760^{\circ} \mathrm{C} / 6$ Hours.

The following observations were apparent:

1. The as-rolled microstructure, Figure 3, reflects the influence of rolling above the recrystallization temperature. The microstructure consists primarily of large, very irregularly distorted, nonuniform grains measuring $\sim 50 \mu \mathrm{m}$ by $\sim 350 \mu \mathrm{m}$, interspersed with areas of small, uniform, equiaxed grains measuring $\sim 15 \mu \mathrm{m}$. The small grains also show evidence of prior work.

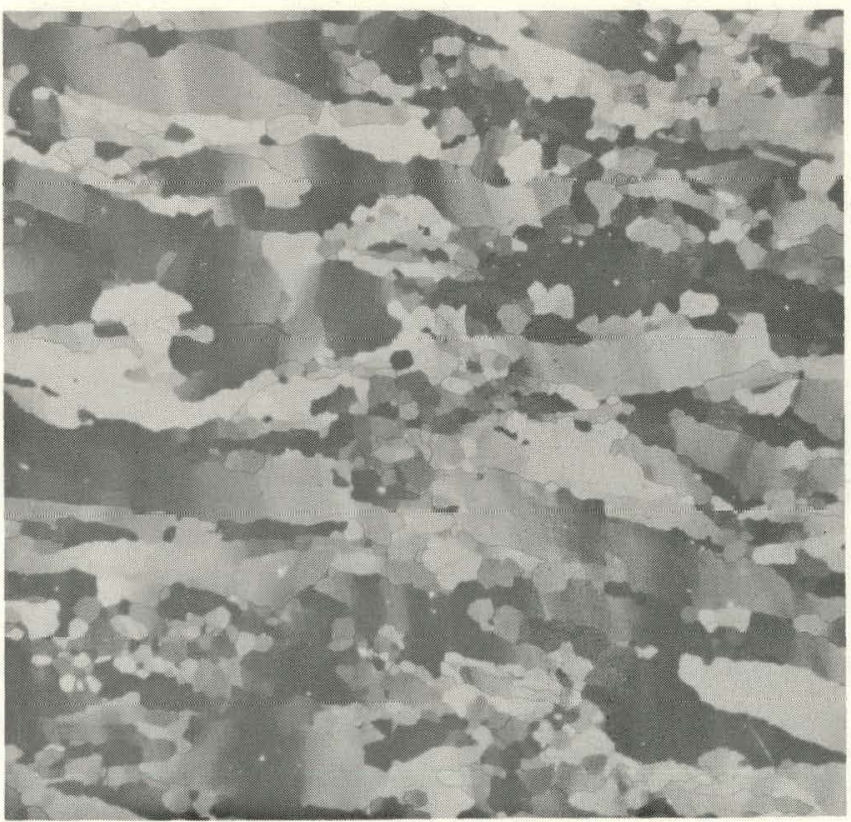

2. Progressive annealing, Figures 4 through 7 caused increased recrystallization and grain growth.

3. Recrystallization was heterogeneous. New grains occurred in clusters which grew in size while much of the structure was unaffected by the particular anneal.

4. The larger nonuniform grains appeared to be relatively insensitive to the annealing treatments.

5. The orientation of the lineal striations or "bend planes" in the larger grains (within $\pm 20^{\circ}$ to the normal to the plane of the sheet) suggests an orienorientation dependence which may explain deformation and recrystallization behavior. Bend planes are produced by nonpure shear slip on the (0001) plane which causes bending or rotation about an 
axis in the (0001) plane. Bend planes in beryllium have been identified both by $\mathrm{x}$-ray evidence and surface markings as $\{1120\}$, secondary prism planes. $^{20}$

\section{STATISTICAL ANALYSIS}

Histograms were constructed using the grain area and $\log _{\mathrm{e}}$ (Grain Area) data to determine which statistic, arithmetic mean or geometric mean, was more descriptive of the microstructure. The class intervals for each of the five, grainarea histograms were arbitrarily chosen as one-fourth the arithmetic standard deviation of that microstructure. Similarly, the class intervals for the $\log _{e}$ (Grain Area) data were chosen as one-third the respective geometric standard deviation.

The grain area frequency histograms are shown in Figures $8 \mathrm{~A}$ through 8E. The data for these curves are listed in Appendix VI. These histograms show all grain distributions to be positively skewed which, in combination with the large differences in the arithmetic standard deviations (see Table 5) indicates that a low confidence could be expected using arithmetic means for inter-distributional comparisons.

The $\log _{\mathrm{e}}$ (Grain Area) versus frequency histograms are shown in Figures 9A through 9E and the corresponding data are listed in Appendix VII. From the bell-shaped distributions it can be concluded that the distributions are approximately log-normal. Such distributions can ordinarily be compared using the geometric mean and standard deviations. ${ }^{21}$ The standard relationship between mean grain size and mechanical properties is the Hall-Petch relationship which is given by:

$$
\sigma_{\epsilon}=\left(\sigma_{0}\right)_{\epsilon}+\mathrm{k} 1^{-1 / 2}
$$

where 1 is the mean grain size and $\sigma$ is some mechanical property at constant strain, $\epsilon$. Investigators ${ }^{14,15}$ have shown that a Hall-Petch relationship is followed by beryllium. However the material evaluation in this study was purposely annealed to have different strain conditions. It is therefore not surprising that neither the arithmetic nor the geometric mean data from Table 5 exhibit a $1^{-1 / 2}$ linear relationship with $0.2 \%$ yield strength. With respect to decreasing yield strength, the geometric mean grain area first decreases and then increases with progressive annealing. While the arithmetic mean does not show the increase, it does level off. This effect can be explained as competing effects of recrystallization and grain growth. Both recrystallization and grain growth are thermally activated, and there is not reason to expect the activation energies to be the same. The first four material conditions reflect the predominant influence of recrystallization which caused the reduction in the arithmetic and geometric mean area. However, the over riding influence of grain growth is observed in the fifth material condition $\left(760^{\circ} \mathrm{C} / 6\right.$ hours), where an increase in the geometric mean grain area is observed. Although the arithmetic mean is not as sensitive to the grain growth, further annealing would cause it to increase also.

Since the arithmetic and geometric means were not suitable for correlating grain area with yield strength, $\log _{\mathrm{e}}$ (Grain Area) cumulative frequency distributions, listed in Appendix VII, were plotted to investigate the influence of the heat treatments on the entire grain size distributions. From these curves, shown in Figure 10, it is apparent that the various anneals produced no simple trends. The median $\log _{e}$ (Grain Area) values (shown at 0.5 cumulative frequency) also did not show any strong correlation with yield strength. However, closer inspection of the curves revealed a qualitative correlation above 0.85 cumulative frequency: higher yield strength material exhibited larger $\log _{e}$ (Grain Area) values in this region, suggesting that the larger grains were strongly influencing the $0.2 \%$ yield strength.

A more guantitative description of the grain distributions was obtained upon plotting the grain area cumulative frequency distributions on log-probability paper. The data are listed in Appendix VI and plotted in Figure 11. Logprobability paper is designed to produce a linear plot from cumulative frequency data of a simple log-normal distribution. Analyses of data show the following:

Table 5. Summary of Statistical Analysis of Grain Measurements.

$\begin{array}{ccc}\begin{array}{c}0.2 \% \text { Yield } \\ \text { Strength } \\ (\mathrm{ksi})\end{array} & \begin{array}{c}\text { Mean Arith. } \\ \text { Grain Area } \\ \left(\mathrm{mm}^{2} \times 10^{-6}\right)\end{array} & \begin{array}{c}\text { Arithmetic } \\ \text { Standard } \\ \text { Deviation }\end{array} \\ 51.1 & 2663 & 5292.9 \\ 45.8 & 2070 & 4778.6 \\ 42.4 & 1944 & 3710.2 \\ 36.5 & 1176 & 3014.4 \\ 32.4 & 1177 & 2319\end{array}$

\begin{tabular}{|c|c|c|c|}
\hline $\begin{array}{c}\text { Geometric } \\
\text { Grain Area } \\
\left(\mathrm{mm}^{2} \times 10^{\circ}\right)\end{array}$ & $\begin{array}{l}\text { Geometric } \\
\text { Standard } \\
\text { Deviation }\end{array}$ & $\begin{array}{l}\text { Grain } \\
\text { L/W } \\
\text { Ratio }\end{array}$ & $\begin{array}{c}\text { Number } \\
\text { of } \\
\text { Grains }\end{array}$ \\
\hline 683 & 6.91 & 4.08 & 484 \\
\hline 523 & 5.58 & 3.45 & 390 \\
\hline 497 & 6.13 & 3.16 & 360 \\
\hline 333 & 3.48 & 2.87 & 638 \\
\hline 504 & 3.72 & 1.75 & 495 \\
\hline
\end{tabular}



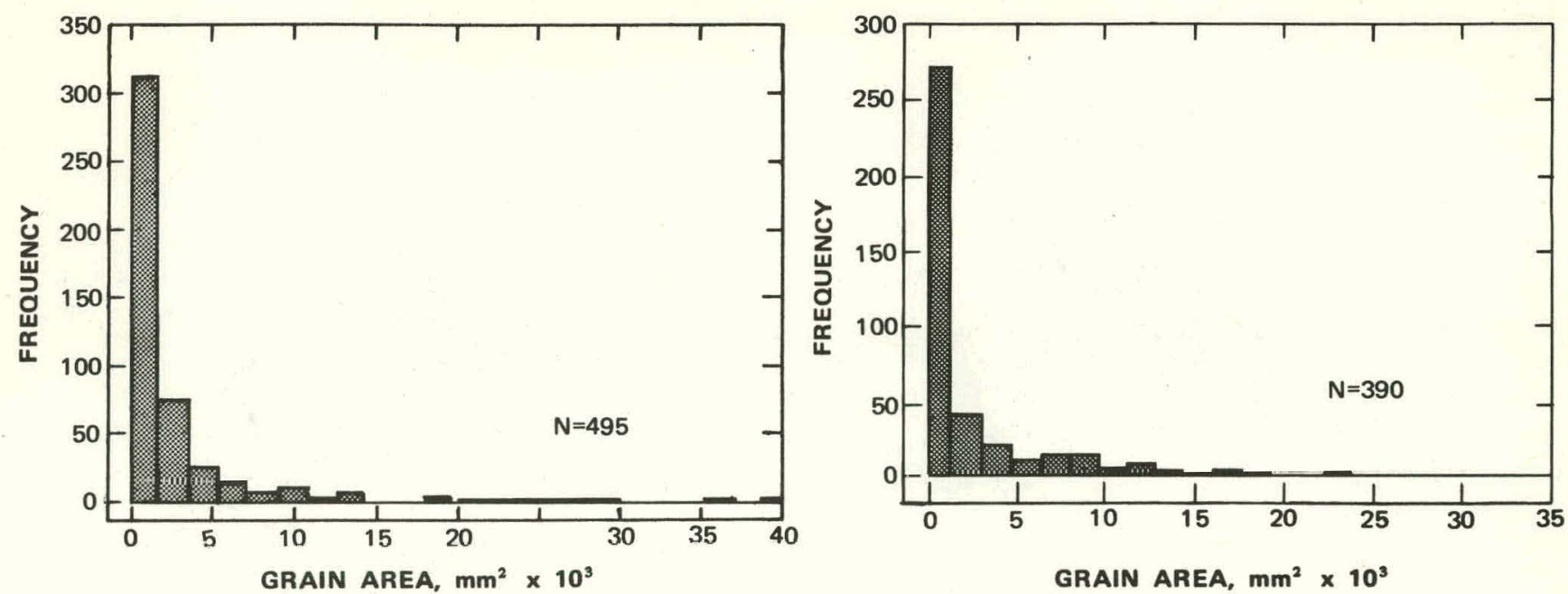

A. As-Rolled

B. After $650^{\circ} \mathrm{C} / 4$ Hours

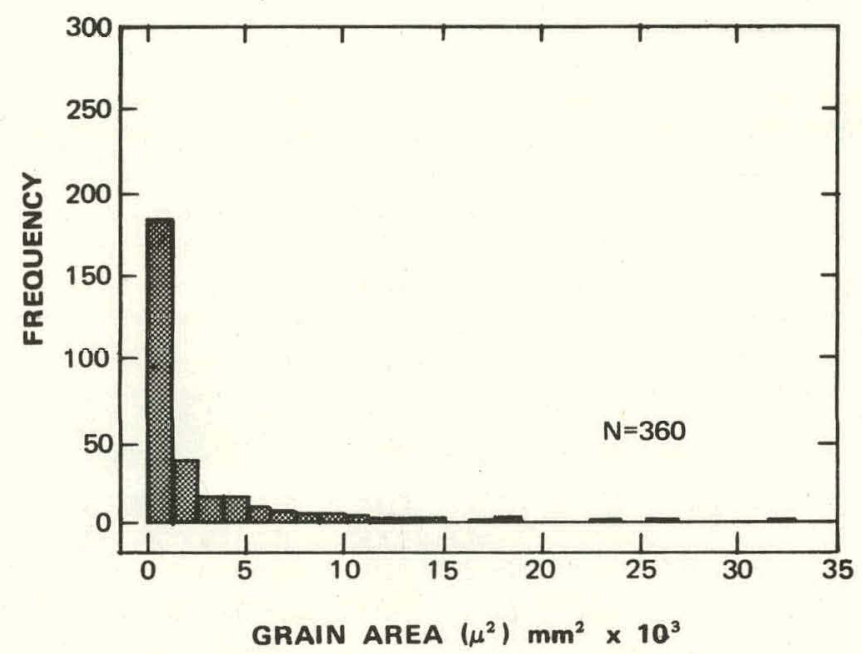

C. After $700^{\circ} \mathrm{C} / 2$ Hours

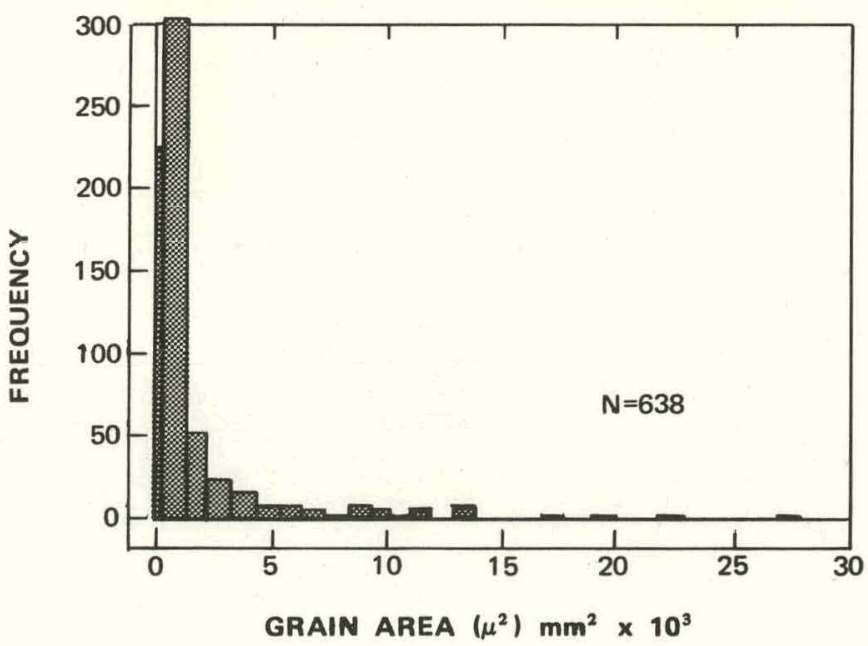

D. After $775^{\circ} \mathrm{C} / 1$ Hour

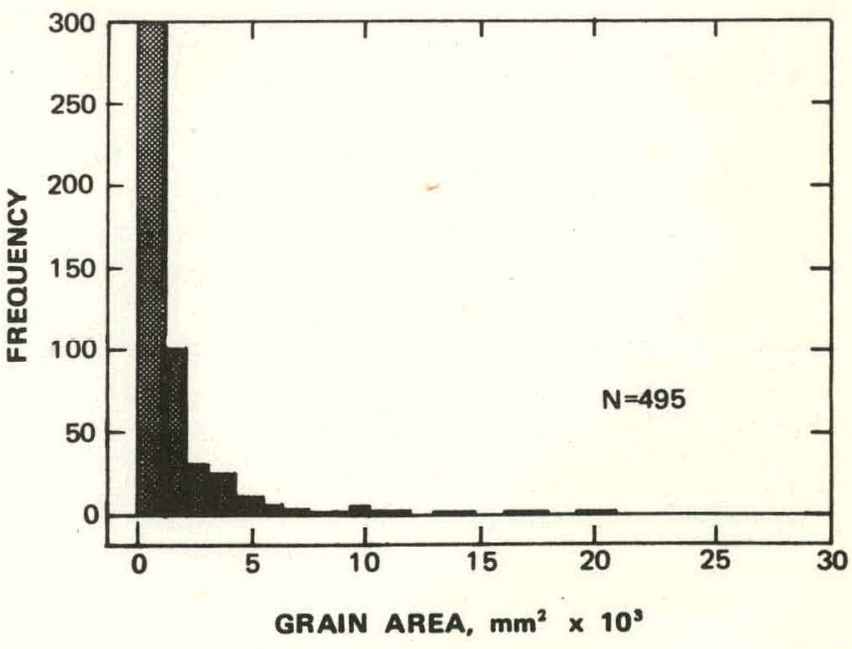

E. After $760^{\circ} \mathrm{C} / 6$ Hours

Figure 8. Grain Area Histograms. 

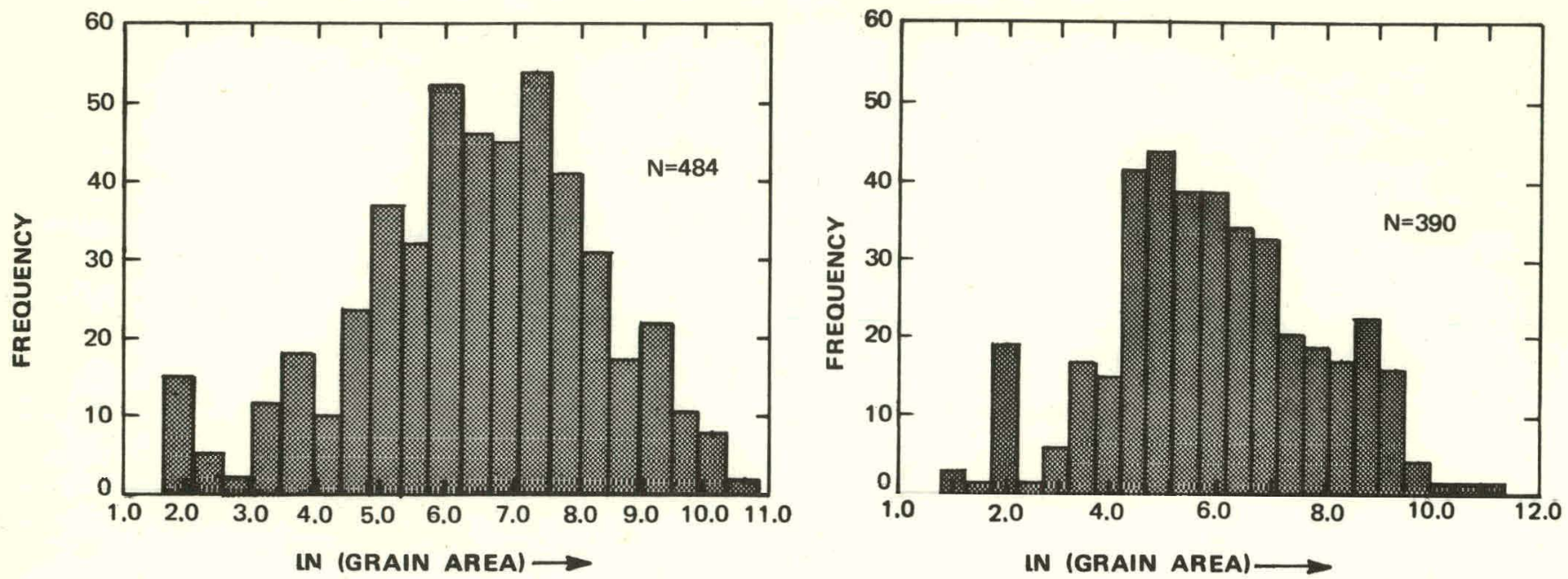

A. As-Rolled

B. After $650^{\circ} \mathrm{C} / 4$ Hours

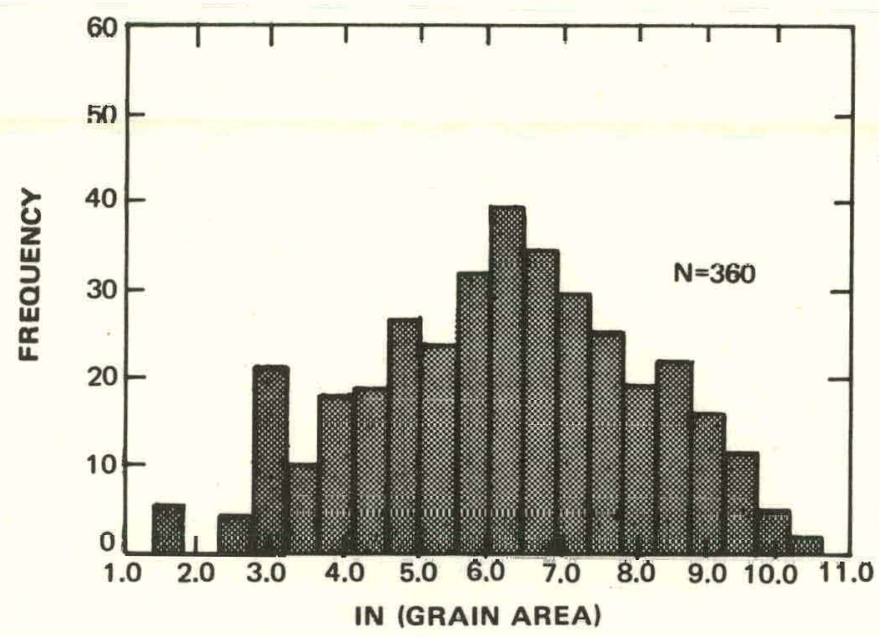

C. After $700^{\circ} \mathrm{C} / 2$ Hours

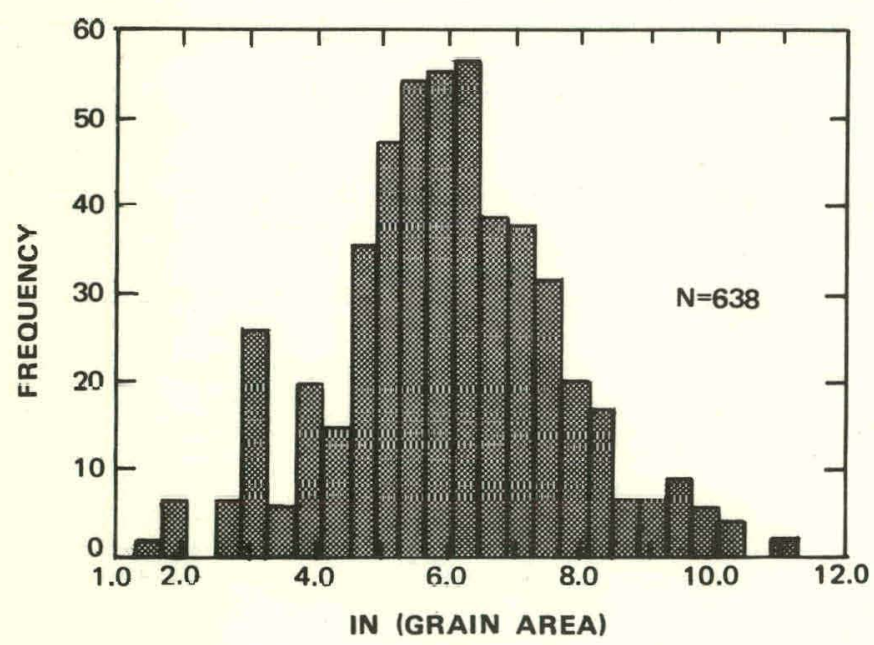

D. After $775^{\circ} \mathrm{C} / 1$ Hour

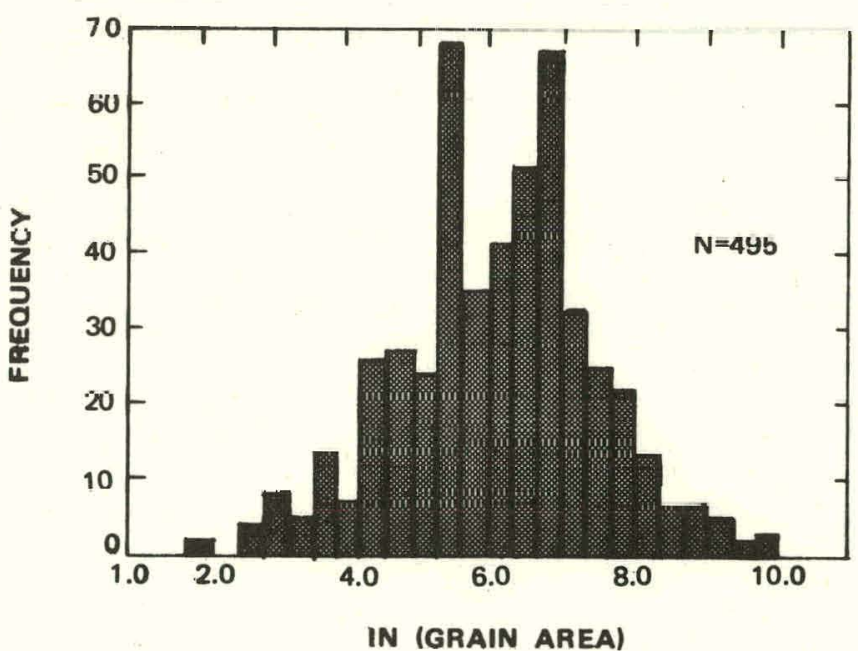

E. After $760^{\circ} \mathrm{C} / 6$ Hours

Figure 9. $\log _{e}$ (Grain Area) Histograms. 


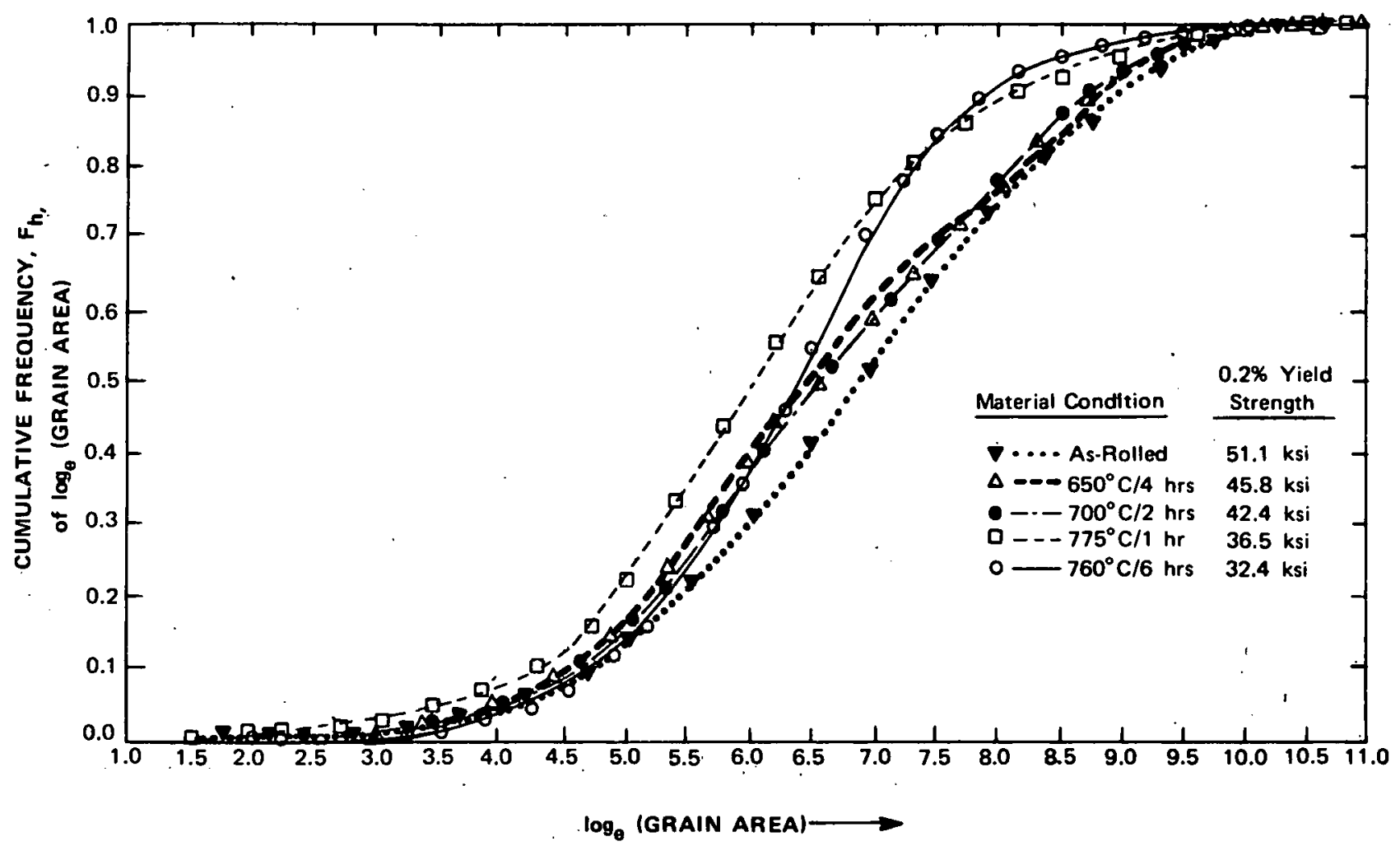

Figure 10. Cumúlative Frequency Distribution of $\log _{\theta}$ (Grain Area) Data.

Figure 11. Cumulative Frequency. Distributions of Grain Area Data.

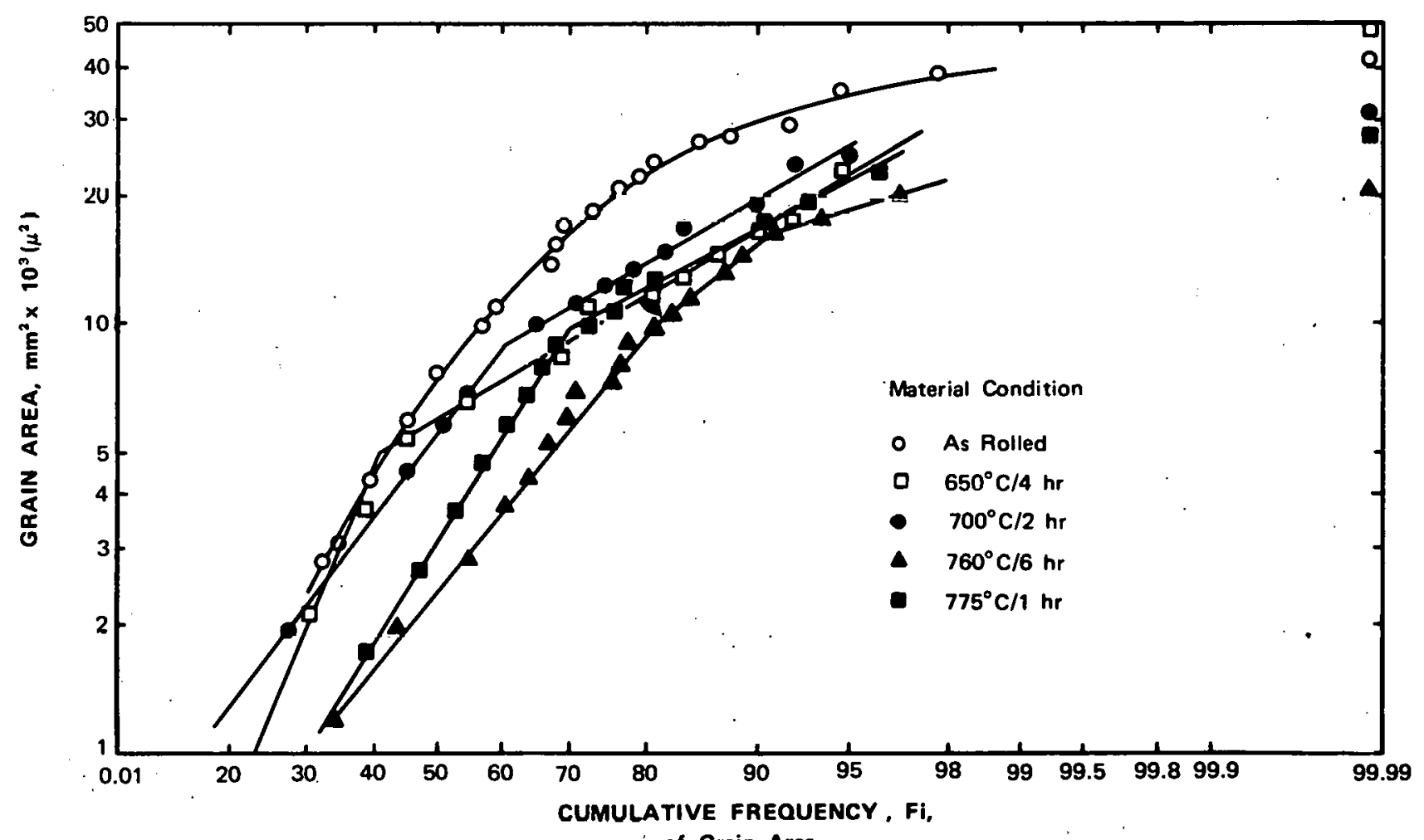

of Grain Area 
1. The as-rolled microstructure grain area distribution, shown in Figure 11, is not a simple log-normal distribution. Apparently the mixed grain sizes produced by reheating and rolling above the recrystallization temp ture do not cause a log-normal distribution in the as-rolled condition.

2. The annealed microstructure distributions in Figure 11 show two intersecting straight lines which indicate a duplexed log-normal distribution.

3. As annealing progresses, the area percentage of total structure occupied by the smaller grain distribution increases and the two distributions tend to form one. The intersection of the two straight lines in the annealed material distributions in Figure 11 indicates the percent of the structure occupied by each distribution.

4. A graph showing the relationship between the percent of the structure occupied by the small grain distribution versus $0.2 \%$ yield strength exhibits a linear relationship. See Figure 12. The as-rolled material did not exhibit a distinguishable distribution separation and therefore could not be plotted.
The increase in the percent of microstructure occupied by the small grain distribution because of increased annealing is caused by recrystallization and grain growth. The reduction in $0.2 \%$ yield strength is directly proportional to the increase in strain-free material. However, the measured effect is not just caused by the increasing amount of new strain-free material because a grain size parameter, not a recrystallized percentage parameter, was measured. In the as-rolled microstructure, Figure 3, a number of the fine grains show evidence of distortion and residual work. Such graino aro aloo prosont in some of the paitially antealed microstructures, see Figures 4 and 5. During the anneals large unrecrystallized grains from the large grain distribution decompose by recrystallization or are consumed by grain growth of recrystallized grains. This effect has been previously observed by Bunce and Evans ${ }^{9}$ and Cheer and Lowe. ${ }^{11}$ Obviously the large grains will be reduced in size until the unreirystallizel purtiun will belong to the small grain distribution. It follows that the percentage of the microstructure occupied by the small grain distribution should not be interpreted as the absolute percentage of strain-free metal, but rather as being proportional to the percentage of strain-free metal.

A second microstructural quantity may be used to predict $0.2 \%$ yield strength in partially annealed ingot source

Figure 12. Relationship Between $0.2 \%$ Yield Strength and the Microstructural Percent Occupied by the Small-Grain Distribution.

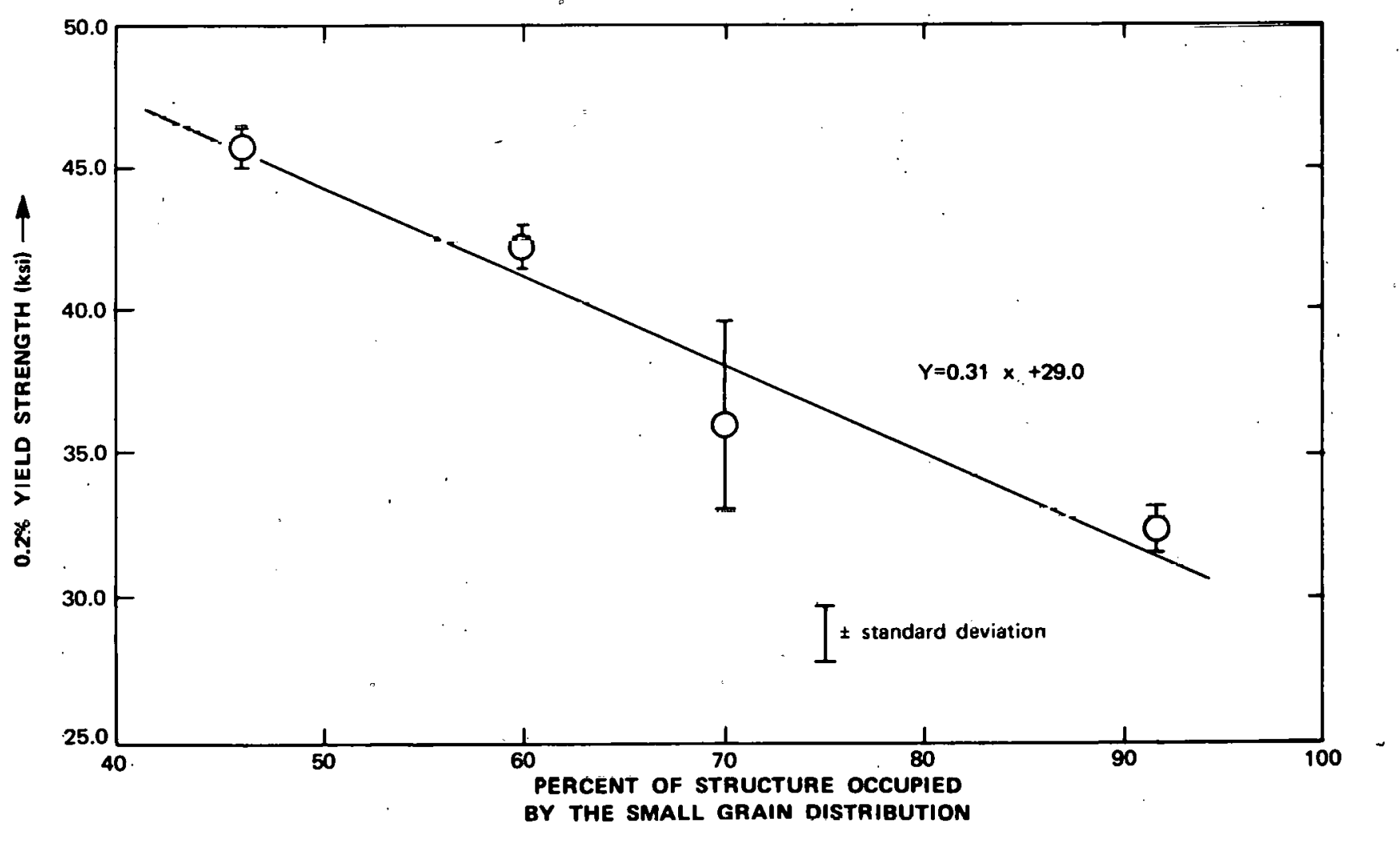


beryllium sheet. The ratio of average grain length-to-width $(\mathrm{L} / \mathrm{W})$ was found to exhibit an approximately linear correlation with $0.2 \%$ yield strength (see Figure 13 ). The data are listed in Appendices IV and $V$. and summarized in Table 5 .

The data show that the average $\mathrm{L} / \mathrm{W}$ ratio was reduced from $4: 1$ in the as-rolled condition to $1.75: 1$ in the most fully annealed condition. Since fully annealed material would exhibit an average $\mathrm{L} / \mathrm{W}$ ratio of $1: 1$, corresponding to $100 \%$ equiaxed grains, it is apparent that the most fully annealed of the five conditions $\left(760^{\circ} \mathrm{C} / 6\right.$ hours) is not fully annealed.

In comparison with the relationship obtained in Figure 12 between the percentage of structure occupied by the small grain distribution and $0.2 \%$ yield strength, the average $\mathrm{L} / \mathrm{W}$ versus $0.2 \%$ yield strength correlation shows slightly more deviation from a linear behavior, particularly in the more fully annealed materials. This is probably caused by the influence of the different annealing temperatures causing nonproportional responses in grain growth and recrystallization. However, an average $\mathrm{L} / \mathrm{W}$ ratio would be: much easier and faster to measure, using the Heyn technique, ${ }^{22}$ than would individual grain-size measurements for a routine process.

\section{INFERENCES FROM MICROSTRUCTURAL ANALYSIS}

\section{Rolling Behavior}

There are several effects which may be responsible for the heterogeneous rolling recrystallization behavior of ingot source beryllium sheet. As previously discussed, rolling is conducted at temperatures above the recrystallization temperature so that one would expect some recrystallization during reheats between passes and perhaps spontaneously during rolling. The recrystallized grains would be "softer" and tend to selectively deform on subsequent passes yielding a mixed, distorted structure. A second contribution to the heterogenous uniform/nonuniform structure is believed to result from the single crystal hardness anisotropy which a number of investigators, ${ }^{23-26}$ have reported. Single

Figure 13. Relationship Between $0.2 \%$ Yield Strength and Average Grain Length-to-Width Ratio.

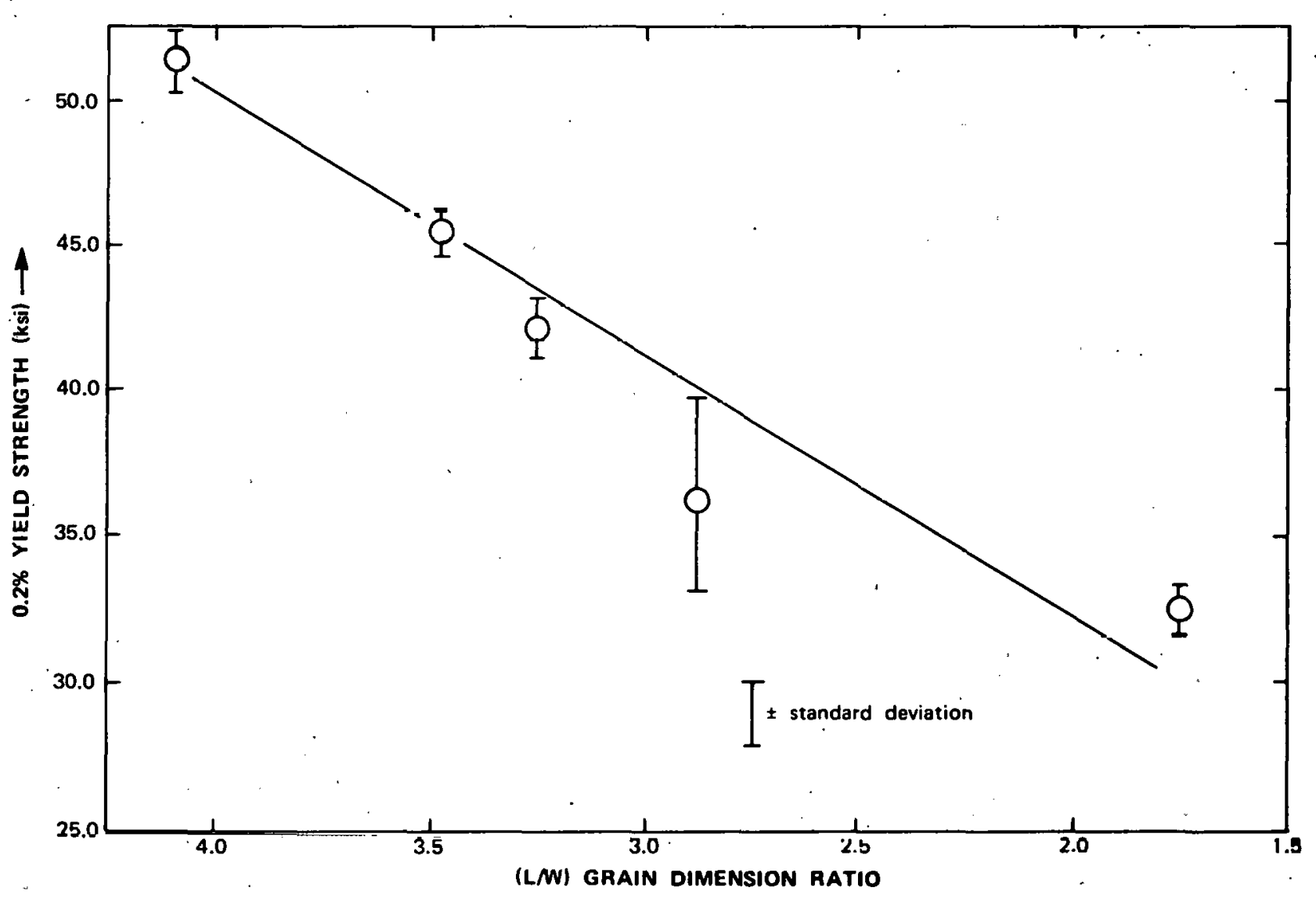


crystal hardness is two to three times greater, parallel to the $\mathrm{C}$-axis than perpendicular to it, at temperatures at least as high as $700^{\circ} \mathrm{C}$. Certain grains having their $\mathrm{C}$-axis approximately normal to the plane of the sheet would resist rolling deformation more than grains having other orientations. The distribution of ben planes which indicate the trace of the $\{1120\}$ planes appears to be within $\pm 20^{\circ}$ of the normal to the plane of the sheet for the large uncrystallized grains (see Figures 3 through 7). This suggests such an orientation relationship may be responsible for the deformation behavior of ingot source beryllium sheet or vice versa. Such observations have also been made by Evans and Bunce, ${ }^{27}$ Cheer and Lowe $\mathrm{e}^{11}$ and others.

\section{Annealing Behavior}

The 0.100-inch-thick ingot-source beryllium sheet exhibited a heterogeneous recrystallization response to the partial anneals of this study: Heterogeneous recrystallization can be expected from heterogeneous deformation; however, effects recently observed by Hulsey, ${ }^{28}$ and previously observed by Tuer et al., ${ }^{13}$ indicate that recrystallization tendencies are also dependent upon the orientations of the crystals during deformation rather that just the amount of deformation. Hulsey's work with single crystals showed that, after rolling pre-oriented beryllium single crystals which were canned in stainless steel, a nonuniform recrystallization response was observed. After one hour at $700^{\circ} \mathrm{C}$ the recrystallization response ranged from less than one percent to over $50 \%$. After one hour at $800^{\circ} \mathrm{C}$ the recrystallization response ranged from less than $10 \%$ to almost $100 \%$ depending on crystal orientation. Although the single crystals were rolled at $540^{\circ} \mathrm{C}$ it seems quite feasible that similar behavior could be expected from grains with polycrystalline beryllium sheet rolled at $780^{\circ} \mathrm{C}$. Again, the distribution of bend plane directions suggests that an orientation-dependent relationship, particularly with the large grains which resist recrystallization, is responsible for the heterogeneous response to annealing.

\section{CONCLUSIONS}

\section{Heat Treatment and Mechanical Property Investigation}

- The ultimate tensile strength of 0.100 -inch-thick, ingotsource beryllium sheet was relatively insensitive to the partial anneals of this investigation; varying from 62.3 $\pm 1.4 \mathrm{ksi}$ in the as-rolled condition to $58.0 \pm 3.5 \mathrm{ksi}$ after 24 hours at $760^{\circ} \mathrm{C}$ in vacuum.

- The $0.2 \%$ yield strength varied from $58.0 \pm 3.5 \mathrm{ksi}$ in the as-rolled conditon to $31.2 \pm 3.5 \mathrm{ksi}$ after 24 hours at $760^{\circ} \mathrm{C}$.
- Elongation values showed an increase from $2.0 \pm 0.93 \%$ in the as-rolled condition to $5.5 \pm 0.46 \%$ after 24 hours at $760^{\circ} \mathrm{C}$.

- Good combinations of ultimate tensile strength and $0.2 \%$ yield strength coupled with good ductility were observed after various partial annealing treatments. For example after 4 hours at $725^{\circ} \mathrm{C}$ the following properties were obtained: $61.3 \pm 3.5 \mathrm{ksi}$ ultimate tensile strength, $40.9 \pm 2.1 \mathrm{ksi} 0.2 \%$ yield strength, and $4.7 \pm 1.7 \%$ elongation.

\section{Microstructural Analysis}

- The 0.100-inch-thick, ingot-source beryllium used in this investigation exhihits heterngenenus grain deformation during rolling and heterogeneous recrystallization response during annealing.

- The as-rolled,grain area distribution is positively skewed; non-normal and non-log-normal. The microstructure consists of mixed areas of large, distorted, unrecrystallized grains measuring $\sim 50 \mu \mathrm{m}$ by $\sim 350 \mu \mathrm{m}$ interspersed with areas of small, uniform, equiaxed grain clusters containing grains averaging about $15 \mu \mathrm{m}$. The small equiaxed grains show evidence of work indicating recrystallization prior to the last rolling pass.

- The large unrecrystallized grains in the as-rolled microstructure are relatively insensitive to recrystallization.

- The distribution of bend plane directions in the unrecrystallized large grains (within approximately $+20^{\circ}$ to the sheet normal) suggests that the large grains have an orientation relationship with the plane of the sheet; this may eyplain their rnlling and res.rystallization behavior.

- The annealed microstructure exhibits duplex log-normal distributions. The small-grain distribution is proportional to the volume of strain-free grains and the large-grain distribution is composed of distorted, unrecrystallized grains.

- Increased annealing causes recrystallization and grain growth which increases the percentage of the microstructure occupied by the small grains and causes the two distributions to merge toward one log-normal distribution.

- Both the percentage of microstructure occupied by the small-grain distribution and the average grain length-towidth ratio show a linear relationship with $0.2 \%$ yield strength, since they vary directly with the percentage of strain-free microstructure. 


\section{Inferences from Microstructural Analyses}

The hetergeneous rolling and recrystallization behavior of polycrystalline ingot-source beryllium sheet are attributed to an orientation relationship of the large grains in the sheet.

\section{RECOMMENDATIONS}

The work on rolling recrystallization of beryllium single crystals, Hulsey, ${ }^{28}$ should be extended from $540^{\circ} \mathrm{C}$ to at least $\sim 780^{\circ} \mathrm{C}$, which is the rolling temperature used in the production of commercial ingot-source beryllium. This work would be useful in optimizing the rolling schedules used for polycrystalline beryllium sheet.

A second interesting study is suggested by the bend plane distributions observed in this study. A two dimensional investigation should be made to confirm the relationship between the bend plane distribution and the basal plane distribution.

Hot stage metallography on as-rolled beryllium sheet might be used to explore optimum time/temperature combinations which could be used to minimize grain size and optimize the mechanical properties of production material.

\section{REFERENCES}

1. H. D. Hanes, Battelle Technical Review, Vol. 17, SeptemberOctober 1968, pp 15-19.

2. L. E. Wilson, private communication.

3. F. J. Fraikor et al., USAEC RFP-1041, Rocky Flats Division, Dow Chemical U.S.A., March 12, 1968.

4. J. A. Carrabine èt al., Beryllium Technology, Proceedings of 2nd International Conference, Edited by L. McDonald Schetky and H. A. Johnson, Philadelphia, Vol. 1, 1966, pp 239-257.

5. A. Moore, Journal of Nuclear Materials, Vol. 3, No. 1., 1961, p 113.

6. H. P. Rooksby, Journal of Nuclear Materials, Vol. 7, No. 2, $1962, \mathrm{p} 205$.

7. J. Greenspan, Beryllium: Its Metallurgy and Mechanical Properttes, Chapter $y$, edited by $\mathrm{H}$. Hausner, University of California Press, Berkeley, 1965, p 254.
8. F. J. Fraikor, private communication.

9. J. E. J. Bunce and R. E. Evans, The Metallurgy of Beryllium, Proceedings of the 1961 International Conference in London, Chapman and Hall, Ltd., 1963, pp 246-263.

10. M. S. Werkema, Journal of A pplied Crystallography, Vol 3, 1970 , p 265.

11. D. A. Cheer and J. N. Lowe, USAEC Conference on Beryllium, Gotlinburg, Tennessee, CONF-170 (1963), pp 160-83.

12. G. V. London and V. V. Damiano, Final Report F-C2445, Franklin Institute, April 1970.

13. G. L. Tuer et al, The Metal Beryllium, Edited by D. W. White, Jr., and J. E. Burke, Chapter VII-D, ASM, 1955, pp 466-1176.

14. R. W. Armstrong, Metallurgical Transactions, Vol. 1, No. 5 , May 1970, pp 1169-1176.

15. J. Greenspan, Report No. NMI-1174, Nuclear Metals, Inc., Cambridge, Mass., Contract AT(30-1)-1565, August 9, 1957.

16. S. Beitscher, USAEC RFP-1205, Rocky Flats Division, Dow Chemical U.S.A., December 11, 1968.

17. W. V. Ward et al., Transactions of ASM, 54, 1961, p 84.

18. C. O. Matthews et al., WADD Technical Report 60-116, USAF, July 1960 .

19. A. E. Calabra and R. J. Jackson, USAEC RFP-962, Rocky Flats Division, Dow Chemical U.S.A., August 7, 1967.

20. G. L. Tuer and A. R. Kaufmann, The Metal Beryllium, Edited by D. W. White, Jr., and J. E. Burke, Chapter VII-B, ASM 1955, p 392.

21. F. Schucker, Quantitative Microscopy, edited by R. T. deHoff and F. N. Rhines, Chapter 7, McGraw-Hill Book Co., New York, 1968, pp 201-265.

22. ASTM Designation E-112-63.

23.. K. Tsuya, Journal of Nuclear Materials, Vol. 22, North Holland Pub. Co., Amsterdam, 1967, pp 148-157.

24. A. R. Kaufmann et al., Transactions of ASM, Vol. 42, 1950, pp 785-844.

25. A. R. Kaufmann, The Metal Beryllium, Edited by D. W. White, Jr., and J. E. Burke, Chapter VII-A. ASM 1955, p 42.1

26. H. T. Lee and R. M. Brick, Final Report on ONR-24908, University of Penn., September 1953.

27. J. E. J. Bunce and R. E. Evans, AWRE Report No. 0-47/63, United Kingdom Atomic Energy Authority, August 1963.

28. W. J. Hulsey, Document Y-1679, Union Carbide Corporation, Y-12 Plant, Oak Ridge, Tennessee, August 18, 1969. 
RFP-1831 
APPENDIX I

Room Temperature Tensile Data from Partially-Annealed Beryllium

\begin{tabular}{|c|c|c|c|c|c|c|c|c|c|}
\hline Condition & $\begin{array}{c}0.2 \% \text { Yield } \\
\text { Strength } \\
\quad \text { (ksi) } \\
\end{array}$ & $\begin{array}{c}\text { Ultimate } \\
\text { Strength } \\
\text { (ksi) } \\
\end{array}$ & $\begin{array}{c}\begin{array}{c}\text { Elongation } \\
(\%)\end{array} \\
\end{array}$ & Remarks' & Condition & $\begin{array}{l}0.2 \% \text { Yield } \\
\text { Strength } \\
\text { (ksi) }\end{array}$ & $\begin{array}{c}\begin{array}{c}\text { Ultimate } \\
\text { Strength } \\
\text { (ksi) }\end{array} \\
\end{array}$ & $\begin{array}{c}\text { Elongation } \\
(\%) \\
\end{array}$ & Remarks \\
\hline \multirow[t]{2}{*}{ As-Rolled (L) } & $\begin{array}{l}50.9 \\
50.8 \\
51.5 \\
\end{array}$ & $\begin{array}{l}62.1 \\
62.8 \\
61.9 \\
\end{array}$ & $\begin{array}{l}2.1 \\
2.3 \\
1.7 \\
\end{array}$ & & $725^{\circ} \mathrm{C} / 4 \mathrm{hr}(\mathrm{L})$ & $\begin{array}{l}40.6 \\
41.7 \\
40.4\end{array}$ & $\begin{array}{l}62.1 \\
61.9 \\
60.0 \\
\end{array}$ & $\begin{array}{l}5.3 \\
4.6 \\
4.2 \\
\end{array}$ & \\
\hline & $\overline{51.1}$ & $\overline{62.3}$ & $\overline{2.0}$ & & & $\overline{40.9}$ & 61.3 & $\overline{4.7}$ & \\
\hline $\begin{array}{l}\text { Standard } \\
\text { Deviation (s.d.) }\end{array}$ & 0.60 & 0.70 & 0.46 & & $\begin{array}{l}\text { Standard } \\
\text { Deviation (s.d.) }\end{array}$ & 1.0 & 1.8 & 0.85 & \\
\hline As-Rolled ( $\mathrm{T}$ ) & $\begin{array}{l}50.5 \\
50.5 \\
50.0\end{array}$ & $\begin{array}{l}55.9 \\
58.5 \\
57.3 \\
\end{array}$ & $\begin{array}{l}0.8 \\
1.2 \\
1.2\end{array}$ & & $760^{\circ} \mathrm{C} / 1 \mathrm{hr}(\mathrm{L})$ & $\begin{array}{l}39.0 \\
40.5 \\
39.6 \\
\end{array}$ & $\begin{array}{l}60.0 \\
61.7 \\
57.0 \\
\end{array}$ & $\begin{array}{l}4.4 \\
4.1 \\
3.3\end{array}$ & . \\
\hline 1. & $\overline{50.3}$ & $\overline{57.2}$ & $\overline{1.1}$ & & & 39.7 & 59.6 & 3.9 & \\
\hline s.d. & 0.44 & 2.00 & 0.35 & & s.d. & 1.2 & 3.6 & 0.85 & \\
\hline $650^{\circ} \mathrm{C} / 2 \mathrm{hr}(\mathrm{L})$ & $\begin{array}{c}46.3 \\
45.9 \\
- \\
\end{array}$ & $\begin{array}{l}61.8 \\
62.2 \\
- \\
\end{array}$ & $\begin{array}{l}3.5 \\
3.8 \\
=\end{array}$ & Broke in pin hole & $760^{\circ} \mathrm{C} / 2 \mathrm{hr}(\mathrm{L})$ & $\begin{array}{l}35.7 \\
36.5 \\
35.7 \\
\end{array}$ & $\begin{array}{l}58.5 \\
61.5 \\
57.6 \\
\end{array}$ & $\begin{array}{l}4.6 \\
5.8 \\
4.3\end{array}$ & \\
\hline & $\overline{46.1}$ & $\overline{62.0}$ & $\overrightarrow{3.6}$ & & & $\overline{36.0}$ & 59.2 & 4.9 & \\
\hline s.d. & 1.80 & 1.80 & 1.85 & & s.d. & 0.70 & 3.1 & 1.2 & \\
\hline $650^{\circ} \mathrm{C} / 4 \mathrm{hr}(\mathrm{L})$ & $\begin{array}{l}45.6 \\
45.9 \\
45.9\end{array}$ & $\begin{array}{l}61.9 \\
61.4 \\
61.6 \\
\end{array}$ & $\begin{array}{l}3.8 \\
3.4 \\
3.3 \\
\end{array}$ & $\cdot$ & $760^{\circ} \mathrm{C} / 6 \mathrm{hr}(\mathrm{L})$ & $\begin{array}{l}32.6 \\
32.2 \\
\text { 32.3 } \\
\end{array}$ & $\begin{array}{l}59.4 \\
56.1 \\
59.7 \\
\end{array}$ & $\begin{array}{l}5.0 \\
4.0 \\
5.8 \\
\end{array}$ & \\
\hline & $\overline{45.8}$ & $\overline{61.6}$ & $\overline{3.5}$ & & & 32.4 & 58.4 & 4.9 & \\
\hline s.d. & 0.26 & 0.38 & 0.40 & & s.d. & 0.32 & 3.0 & 1.4 & \\
\hline $650^{\circ} \mathrm{C} / 6 \mathrm{hr}(\mathrm{L})$ & $\begin{array}{l}46.2 \\
46.3 \\
46.4 \\
\end{array}$ & $\begin{array}{r}58.9 \\
58.4 \\
59.9 \\
\end{array}$ & $\begin{array}{l}2.4 \\
2.2 \\
2.7 \\
\end{array}$ & & $760^{\circ} \mathrm{C} / 24 \mathrm{hr}(\mathrm{L})$ & $\begin{array}{l}31.4 \\
32.3 \\
30.0 \\
\end{array}$ & $\begin{array}{l}58.2 \\
59.1 \\
56.8 \\
\end{array}$ & $\begin{array}{l}5.3 \\
5.6 \\
5.5 \\
\end{array}$ & \\
\hline & $\overline{46.3}$ & $\overline{59.1}$ & $\overline{2.4}$ & . & - & $\overline{31.2}$ & $\overline{58.0}$ & $\overline{5.5}$ & \\
\hline s.d. & 0.15 & 1.6 & 0.38 & & s.d. & 1.8 & 1.8 & 0.23 & \\
\hline $675^{\circ} \mathrm{C} / 2 \mathrm{hr}(\mathrm{L})$ & $\begin{array}{l}44.6 \\
40.2 \\
44.5\end{array}$ & $\begin{array}{l}61.1 \\
55.2 \\
57.9\end{array}$ & $\begin{array}{l}3.6 \\
3.5 \\
2.5\end{array}$ & & $\begin{array}{l}775^{\circ} \mathrm{C} / 15 \mathrm{~min} \\
\text { (L) }\end{array}$ & $\begin{array}{l}37.5 \\
36.7 \\
- \\
\end{array}$ & $\begin{array}{l}60.5 \\
61.1 \\
- \\
\end{array}$ & $\begin{array}{r}5.2 \\
5.5 \\
- \\
\end{array}$ & Broke in pin hole \\
\hline , & $\overline{43.1}$ & $\overline{58.1}$ & $\overline{3.2}$ & & & $\overline{37.1}$ & $\overline{60.8}$ & $\overline{5.4}$ & \\
\hline s.d. & $\cdot 3.8$ & 4.5 & 0.90 & & s.d. & 0.85 & 0.65 & 0.28 & \\
\hline $675^{\circ} \mathrm{C} / 4 \mathrm{hr}(\mathrm{L})$ & $\begin{array}{l}43.3 \\
43.3 \\
39.1 \\
\end{array}$ & $\begin{array}{l}61.5 \\
62.1 \\
53.0 \\
\end{array}$ & $\begin{array}{l}4.2 \\
3.9 \\
3.0 \\
\end{array}$ & & $\begin{array}{l}775^{\circ} \mathrm{C} / 30 \mathrm{~min} \\
\text { (L) }\end{array}$ & $\begin{array}{l}34.8 \\
34.7 \\
35.2 \\
\end{array}$ & $\begin{array}{l}56.6 \\
58.9 \\
59.1 \\
\end{array}$ & $\begin{array}{l}5.4 \\
5.0 \\
5.8\end{array}$ & \\
\hline & $\overline{42.2}$ & $\overline{58.9}$ & $\overline{3.7}$ & & & 34.9 & 58.2 & 5.4 & \\
\hline s.d. & 4.2 & 7.8 & 0.95 & & s.d. & 0.46 & 2.1 & 0.60 & \\
\hline $700^{n} \mathrm{C} / 2 \mathrm{hr}(\mathrm{L})$ & $\begin{array}{l}42.8 \\
41.9 \\
38.3^{*}\end{array}$ & $\begin{array}{l}58.7 \\
60.9 \\
53.4^{*}\end{array}$ & $\begin{array}{l}3.0 \\
4.5 \\
3.6\end{array}$ & Insufficiently & $775^{\circ} \mathrm{C} / 1 \mathrm{hr}(\mathrm{L})$ & $\begin{array}{l}35.4 \\
37.6 \\
36.5 \\
\end{array}$ & $\begin{array}{l}56.9 \\
61.5 \\
59.1 \\
\end{array}$ & $\begin{array}{l}4.1 \\
5.5 \\
5.2 \\
\end{array}$ & \\
\hline & 42.4 & 59.9 & 3.8 & ctched to remove & & $\overline{36.5}$ & $\overline{59.2}$ & $\overline{4.9}$ & \\
\hline s.d. & 0.32 & 0.60 & 0.38 & & s.d. & 1.6 & 3.5 & 1.1 & \\
\hline $700^{\circ} \mathrm{C} / 4 \mathrm{hr}(\mathrm{L})$ & $\begin{array}{l}41.4 \\
41.9 \\
40.3\end{array}$ & $\begin{array}{l}58.5 \\
61.6 \\
61.1\end{array}$ & $\begin{array}{l}5.3 \\
4.3 \\
5.3\end{array}$ & & $775^{\circ} \mathrm{C} / 2 \mathrm{hr}(\mathrm{L})$ & $\begin{array}{l}29.8^{*} \\
30.6^{*} \\
29.7^{*}\end{array}$ & $\begin{array}{l}52.2^{*} \\
53.4^{*} \\
52.0^{*}\end{array}$ & $\begin{array}{l}4.4^{*} \\
5.3^{*} \\
5.0^{*}\end{array}$ & $\begin{array}{l}\text { Insufficiently } \\
\text { etched to remove } \\
\text { machine damage }\end{array}$ \\
\hline & $\overline{41.2}$ & $\overline{60.4}$ & $\overline{5.0}$ & & & $\overline{30.3^{*}}$ & $\overline{52.5} *$ & $4.9 *$ & \\
\hline s.d. & 1.3 & 2.5 & 1.5 & & s.d. & $0.75 *$ & $1.2 *$ & $0.70^{*}$ & \\
\hline $725^{\circ} \mathrm{C} / 2 \mathrm{hr}(\mathrm{L})$ & $\begin{array}{l}40.1 \\
39.8 \\
40.3 \\
\end{array}$ & $\begin{array}{l}59.5 \\
61.9 \\
60.6 \\
\end{array}$ & $\begin{array}{l}3.7 \\
5.0 \\
4.9\end{array}$ & . & $775^{\circ} \mathrm{C} / 4 \mathrm{hr}(\mathrm{L})$ & $\begin{array}{l}34.2 \\
29.0 \\
32.0\end{array}$ & $\begin{array}{l}58.9 \\
50.8^{*} \\
54.8^{*}\end{array}$ & $\begin{array}{l}4.8 \\
5.1 \\
5.7\end{array}$ & $\begin{array}{l}\text { Insufficiently } \\
\text { etched to remove }\end{array}$ \\
\hline & $\overline{40.1}$ & $\overline{60.7}$ & $\overline{4.4}$ & & & $\overline{34.2}$ & $\overline{58.9}$ & 4.8 & machine damage \\
\hline s.d. & 0.40 & 1.8 & 1.1 & & s.d. & - & - & - & \\
\hline
\end{tabular}




\section{APPENDIX ||}

\section{Statistical Calculations of Significance for $0.2 \%$ Yield Strength Data}

\begin{tabular}{|c|c|c|c|}
\hline $\begin{array}{c}\text { Material } \\
\text { Condition }\end{array}$ & $\begin{array}{c}\text { Number of } \\
\text { Samples }\end{array}$ & $\begin{array}{c}\text { Sample } \\
\text { Mean, ksi } \\
\end{array}$ & $\begin{array}{c}\text { Sample } \\
\text { Variance } \\
\mathrm{S}_{\mathrm{i}}{ }^{2} \\
\end{array}$ \\
\hline As-Rolled & 3 & 51.1 & 0.143 \\
\hline $650^{\circ} \mathrm{C} / 4 \mathrm{hr}$ & 3 & 45.8 & 0.030 \\
\hline $700^{\circ} \mathrm{C} / 2 \mathrm{hr}$ & 2 & 42.4 & 0.124 \\
\hline $775^{\circ} \mathrm{C} / 1 \mathrm{hr}$ & 3 & 36.5 & $1: 210$ \\
\hline $760^{\circ} \mathrm{C} / 6 \mathrm{hr}$ & 3 & 32.4 & 0.0432 \\
\hline
\end{tabular}

A. " $t$ " Test Results of Significance Bctween Two Sample Mcans (99\% Confidence Level).

$$
t_{c}=\frac{\bar{X}_{1}-\bar{X}_{2}}{\sqrt{\frac{\left(N_{1}-1\right) S_{1}^{2}+\left(N_{2}-1\right) S_{2}^{2}}{N_{1}+N_{2}-2}\left(\frac{1}{N_{1}}+\frac{1}{N_{2}}\right)}}
$$

If $t_{c}>t_{a}$, difference between sample means is real.

As-Rolled versus $650^{\circ} \mathrm{C} / 4 \mathrm{hr}$.

$$
\begin{aligned}
& t_{c}=22.0 \\
& t_{a}=2.132 \\
& \text { Difference is real }
\end{aligned}
$$

$650^{\circ} \mathrm{C} / 4 \mathrm{hr}$ versus $700^{\circ} \mathrm{C} / 2 \mathrm{hr}$

$$
\begin{aligned}
& \mathrm{t}_{c}=13.4 \\
& \mathrm{t}_{a}=2.353
\end{aligned}
$$

Difference is real

$700^{\circ} \mathrm{C} / 2 \mathrm{hr}$ versus $775^{\circ} \mathrm{C} / 1 \mathrm{hr}$

$$
\begin{aligned}
& t_{c}=7.93 \\
& t^{t_{a}}=2.353
\end{aligned}
$$

Difference is real

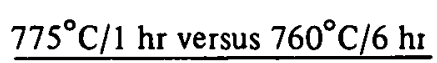

$$
\begin{aligned}
& \mathrm{t}_{\mathrm{c}}=5.54 \\
& \mathrm{t}_{a}=2.132
\end{aligned}
$$

Difference is real

B. "F" Test Results of Significance Between Variances ( $99 \%$ confidence level)

$$
\mathrm{F}_{\mathrm{c}}=\frac{\mathrm{S}_{1}^{2}}{\mathrm{~S}_{2}^{2}}, \text { where } \mathrm{S}_{1}^{2}>\mathrm{S}_{2}^{2}
$$

If $F_{c}<F_{a}$, there is no significant difference between variances.

As Rolled versus $650^{\circ} \mathrm{C} / 4 \mathrm{hr}$

$$
F_{c}=4.78
$$

$$
\mathrm{F}_{a}=99.01
$$

No significant difference in variances

$650^{\circ} \mathrm{C} / 4 \mathrm{hr}$ versus $700^{\circ} \mathrm{C} / 2 \mathrm{hr}$

$$
\begin{aligned}
& F_{c}=4.13 \\
& F_{a}=4.999
\end{aligned}
$$

No significant difference in variances

$700^{\circ} \mathrm{C} / 2 \mathrm{hr}$ versus $775^{\circ} \mathrm{C} / 1 \mathrm{hr}$

$$
\begin{aligned}
& F_{c}=9.78 \\
& F_{a}=4999
\end{aligned}
$$

No significant difference in variances

$775^{\circ} \mathrm{C} / 1 \mathrm{hr}$ versus $760^{\circ} \mathrm{C} / 6 \mathrm{hr}$

$$
\begin{aligned}
& F_{c}=20.8 \\
& F_{a}=99.01
\end{aligned}
$$

No significant difference in variances 


\section{APPENDIX III}

Summary of Metallographic Grinding and Polishing Procedures (Reference 19)

After the metallographic samples have been mounted in a suitable mounting material, rough polishing is performed on successive $60,180,240,320,400,600$, and 600 soft [Buehler (Microcut) paper; Adolf I. Buehler, Inc., Evanston, Illinois] abrasive papers using moderate pressure and liberal amounts of water for lubrication. It is recommended that the papers be changed frequently to prevent smeared metal, and approximately $1 / 16$ inch of material should be removed to ensure elimination of machine and grinding damage. Between each grit size it is also recommended that the specimens be etched for 10 seconds in a 10 vol\% sulfuric acid aqueous solution.

Final polishing is accomplished using automatic polishing units of the rotary or vibratory type. Successive polishing steps utilize $6 \mu, 3 \mu, 1 \mu$, and $1 / 4 \mu$ diamond abrasives with a watersoluble lubricant and respective polishing times of $15,15,5$, and 3 minutes. Specimens are etched with a $2 \%$ hydrofluoric acid - ethyl alcohol solution for five seconds after each final polishing step to aid elimination of smeared metal. The last polishing step was conducted with a $0.05-\mu \mathrm{m}$ gamma alumina using a $0.33 \%$ aqueous solution of chromic acid for lubricant. The samples were vibratory polished for 24 hours and examined by polarized light. 


\section{APPENDIX IV}

\section{Sample of Grain-Measurement Data}

\section{A. As Rolled Microstructure - Area 1}

\begin{tabular}{|c|c|c|c|c|c|c|c|}
\hline \multicolumn{2}{|c|}{ Measured at $200 \mathrm{X}$} & \multirow{2}{*}{$\begin{array}{c}\text { Converted } \\
\text { Area } \\
10^{-6} \mathrm{~mm}^{2}\end{array}$} & \multirow[b]{2}{*}{$\begin{array}{c}\log \text { (Grain } \\
\text { Area) }\end{array}$} & \multicolumn{2}{|c|}{ Measured at $200 \mathrm{X}$} & \multirow{2}{*}{$\begin{array}{c}\text { Converted } \\
\text { Area } \\
10^{-6} \mathrm{~mm}^{2} \\
\end{array}$} & \multirow[b]{2}{*}{$\begin{array}{c}\log \text { (Grain } \\
\text { Area) }\end{array}$} \\
\hline length, mm & $\begin{array}{c}\text { average } \\
\text { width, } \mathrm{mm}\end{array}$ & & & length, $\mathrm{mm}$ & $\begin{array}{c}\text { average } \\
\text { width, } \mathrm{mm}\end{array}$ & & \\
\hline 60 & 11 & 16500 & 9.71112 & 3.5 & 1.5 & 131.25 & 4.87710 \\
\hline 40 & 12 & 12000 & 9.39266 & 23.5 & 6 & 3525 & 8.16764 \\
\hline 14 & 4 & 1400 & 7.24423 & 3 & 2 & 150 & 5.01064 \\
\hline 29 & 5.5 & 3987.5 & 8.29092 & 2 & 2 & 100 & 4.60517 \\
\hline 3 & 3 & 225 & 5.41610 & 31 & 2.5 & 1937.5 & 7.56398 \\
\hline 1.5 & 1 & 37.5 & 3.62434 & 3 & 3 & 225 & 5.41610 \\
\hline 1 & 1 & 25 & 3.21888 & 15 & 10 & 3750 & 8.22951 \\
\hline 20 & 4 & 2000 & 7.60090 & 13 & 3 & 975 & 6.88294 \\
\hline 3 & 3 & 225 & 5.41610 & 24 & 5.5 & 3300 & 8.10168 \\
\hline 14 & 5.5 & 1925 & 7.56268 & 13 & 3 & 975 & 6.88244 \\
\hline 3. & 1.5 & 112.5 & 4.72295 & 10 & 3 & 750 & 6.62007 \\
\hline 3 & 1.5 & 112.5 & 4.72295 & 2.5 & 1 & 62.5 & 4.13517 \\
\hline 22 & 6 & 3300. & 8.10168 & 7.5 & 2 & 375 & 5.92693 \\
\hline 1.5 & 1 & 37.5 & 3.62434 & 31 & 5 & 3875 & 8.2623 \\
\hline 3 & 2.5 & 187.5 & 5.23378 & 24 & 6 & 3600 & 8.18869 \\
\hline 14 & 4.5 & 1575. & 7.36201 & 7.5 & 3 & 562.5 & 6.33239 \\
\hline 0.5 & 0.5 & 6.25 & 1.83258 & 34 & 4 & 3400 & 8.13153 \\
\hline 24 & 3.5 & 2100 & 7.64969 & 67 & 8 & 13400 & 9.50301 \\
\hline 6 & 4 & 600 & $6.39693^{\circ}$ & 38 & 4 & 3800 & 8.24276 \\
\hline 19.5 & 6 & 2925 & 7.98105 & 2 & 2 & 100 & 4.60517 \\
\hline 14.5 & 3 & 1087.5 & 6.99164 & 3 & 0.5 & 37.5 & 3.62434 \\
\hline 32 & 4 & 3200 & 8.07091 & 27 & 8 & 5400 & 5.59415 \\
\hline 3.5 & 0.5 & 43.75 & 3.77849 & 8.5 & 4 & 850 & 6.74524 \\
\hline 4 & 0.5 & 50 & 3.91202 & 19 & 4 & 1900 & 7.54961 \\
\hline 12 & 2 & 600 & 6.39693 & 11 & 3.5 & 967.5 & 6.86953 \\
\hline 13.5 & 1.5 & 506.25 & 6.22703 & 4 & 2 & 200 & 5.29832 \\
\hline 11.5 & 3 & 862.5 & 6.75984 & 1 & 1 & 25 & 3.21888 \\
\hline 18.5 & 3 & 1387.5 & 7.23526 & 6 & 2 & 300 & 5.29832 \\
\hline 8 & 5 & 1000 & 6.90776 & 0.5 & 0.5 & 6.25 & 1.83258 \\
\hline $17:$ & 5 & 2125 & 7.66153 & 0.5 & 0.5 & 6.25 & 1.83258 \\
\hline 3.5 & 3.5 & 306.25 & 5.72440 & 3 & 2 & 150 & 5.01064 \\
\hline 1.5 & 1.5 & 56.25 & 4.02981 & 17 & 2.5 & 1062.5 & 6.96838 \\
\hline
\end{tabular}


RFP-1831

APPENDIX IV 


\section{APPENDIX V}

\section{Statistics From Computer Analyses of Grain Area Data}

I. AS-ROLLED MICROSTRUCTURE.

$\begin{array}{ccccccc}\frac{\text { Area }}{1} & \frac{\overline{\mathrm{X}}_{\mathrm{A}}{ }^{1}}{2261.93} & \frac{\mathrm{S}_{\mathrm{A}}{ }^{2}}{4201.1} & \frac{\ln \left(\mathrm{X}_{\mathrm{G}}\right)^{3}}{6.39656} & \frac{\ln \left(\mathrm{S}_{\mathrm{G}}\right)^{2}}{1.88509} & \frac{\mathrm{N}}{127} & \frac{\mathrm{L} / \mathrm{W}}{4.34} \\ 2 & 2513.32 & 2840.2 & 6.25047 & 2.05781 & 126 & 4.39 \\ 3 & 3824.64 & 7661.0 & 7.01732 & 1.54273 & 105 & 3.42 \\ \frac{4}{\text { All }} & \underline{2251.89} & \underline{440.4} & \underline{6.44284} & \underline{1.85064} & \underline{126} & \underline{4.09} \\ \text { Areas } & 2663.78 & 5292.9^{4} & 6.52591 & 1.93318^{4} & 484 & 4.08\end{array}$

II. $\quad 650^{\circ} \mathrm{C} / 4$ HR MICROSTRUCIURE.

\begin{tabular}{|c|c|c|c|c|c|c|}
\hline 1 & 1954.78 & 3267.0 & 6.32095 & 1.71954 & 140 & 3.60 \\
\hline 2 & 1930.03 & 3595.8 & 6.13514 & 1.80778 & 126 & 3.52 \\
\hline 3 & 2341.48 & 6870.4 & 6.31460 & 1.68176 & 124 & 3.21 \\
\hline $\begin{array}{c}\text { All } \\
\text { Areas }\end{array}$ & 2069.73 & $4778.6^{4}$ & 6.25890 & $1.73681^{4}$ & .390 & 3.45 \\
\hline
\end{tabular}

III. $700^{\circ} \mathrm{C} / 2$ HR MICROSTRUCTURE.

$\begin{array}{ccccccc}1 & 2504.58 & 4341.2 & 6.48294 & 1.81958 & 123 & 3.18 \\ 2 & 2119.89 & 4239.6 & 6.24368 & 1.87903 & 114 & 3.38 \\ \frac{3}{\text { All }} & \underline{1235.22} & \underline{2256.0} & \underline{5.90475} & \underline{1.73977} & \underline{123} & \underline{2.93} \\ \text { Areas } & 1943.66 & 3710.2^{4} & .6 .20963 & 1.81201^{4} & 360 & 3.16\end{array}$

IV. $775^{\circ} \mathrm{C} / 1 \mathrm{HR}$ MICROSTRUCTURE.

\begin{tabular}{ccccccc}
1 & 1387.89 & 3411.8 & 5.94748 & 1.56280 & 207 & 2.50 \\
2 & 1002.44 & 2229.8 & 5.86626 & 1.39375 & 140 & 2.89 \\
3 & 1443.83 & 4443.6 & 5.75168 & 1.75764 & 141 & 3.05 \\
4 & $\underline{805.234}$ & $\underline{1959.5}$ & $\underline{5.54400}$ & $\underline{1.55203}$ & $\underline{150}$ & $\underline{3.18}$ \\
\hline All & & & & & & \\
Areas & 1175.76 & $3014.4^{4}$ & .5 .80942 & $1.24756^{4}$ & 638 & 2.87
\end{tabular}

V. $760^{\circ} \mathrm{C} / 6 \mathrm{HR}$ MICROSTRUCTURE.

\begin{tabular}{lllllll}
1 & 1042.01 & 1875.9 & 6.20790 & 1.18659 & 195 & 1.49 \\
2 & 1516.83 & 2840.2 & 6.51498 & 1.30712 & 124 & 2.25 \\
3 & 1086.27 & $\underline{2375.3}$ & $\underline{6.03136}$ & $\underline{1.44857}$ & $\underline{176}$ & $\underline{1.69}$ \\
\hline All & & & & & & \\
Areas & 1176.69 & $2319.1^{4}$ & 6.22205 & $1.31479^{4}$ & 495 & 1.75
\end{tabular}


NOTES:

(1) $\quad \overline{\mathrm{X}}_{\mathrm{A}}=\sum_{\mathrm{i}=1}^{\mathrm{n}} \mathrm{X}_{\mathrm{i}} \quad$ Arithmetic Mean

(2) $\quad s_{i}=\left[\frac{\sum^{n} x_{i}^{2}-\left(\sum^{n} x_{i}\right) 2 / n}{n-1}\right]^{1 / 2}$

Standard Deviation

(3) $\mathrm{X}_{\mathrm{G}}=\left(\mathrm{X}_{1} \cdot \mathrm{X}_{2} \cdot \mathrm{X}_{3} \cdots \mathrm{X}_{\mathrm{n}}\right)^{1 / \mathrm{n}} \quad$ Geometric Mean

(4) $\quad\left(S_{i}\right)_{p}=\left[\frac{\sum^{n}\left(n_{j}-1\right) S_{i}{ }^{2}}{\sum^{n}\left(n_{i}-1\right)}\right]^{1 / 2}$ Pooled Standard Deviation

Specifically:

$\mathrm{S}_{\mathrm{A}}=$ Arithmetic Standard Deviation

$\mathrm{S}_{\mathrm{G}} \quad=$ Arithmetic Standard Deviation of $\ln \left(\mathrm{X}_{\mathrm{G}}\right)$

$\left(\mathrm{S}_{\mathrm{A}}\right)_{\mathrm{p}}=$ Pooled Arthmetic Standard Deviation

$\left(S_{G}\right)_{p}=$ Pooled Arithmetic Standard Deviation of $\ln \left(X_{G}\right)$

L/W = Average Grain Length.To-Width Ratio. 


\section{APPENDIX VI}

\section{Grain Area Histogram and Cumulative Frequency Distribution Data}

A. AS-ROLLED MICROSTRUCTURE.

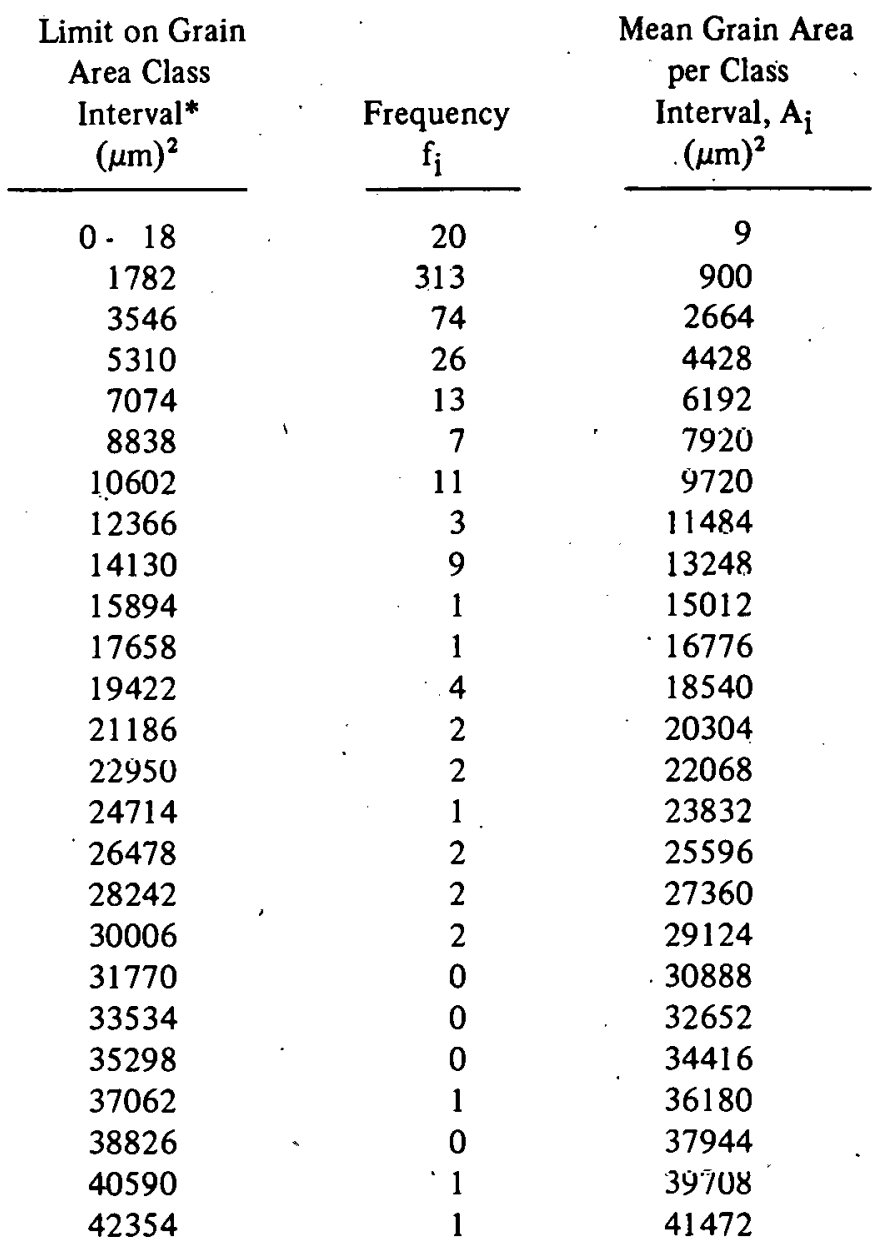

Tot. Grain Area

per Class Interval

\begin{tabular}{rc}
$\begin{array}{c}A_{j}=f_{i} \cdot A_{i} \\
(\mu \mathrm{m})^{2}\end{array}$ & $\begin{array}{c}\text { Cumulative Frequency } \\
F_{h}=A_{j} / A_{j}\end{array}$ \\
\cline { 1 - 2 } 180 & 0.000121 \\
281700 & .190 \\
197136 & .322 \\
115128 & .400 \\
80496 & .454 \\
55692 & .491 \\
106920 & .563 \\
34450 & .586 \\
119232 & .666 \\
15012 & .676 \\
16776 & .688 \\
74160 & .738 \\
40608 & .765 \\
44136 & .795 \\
23832 & .811 \\
51192 & .845 \\
54720 & .882 \\
58238 & .921 \\
0 & .921 \\
0 & .921 \\
0 & .921 \\
36180 & .945 \\
0 & .945 \\
39708 & .972 \\
41472 & 1.000
\end{tabular}

B. $\quad 650^{\circ} \mathrm{C} / 4 \mathrm{HR}$ MICROSTRUCTURE.

$\begin{array}{rrrrr}0-1274 & 272 & 637 & 173264 & 0.203 \\ 2867 & 42 & 2071 & 86982 & .305 \\ 4460 & 20 & 2664 & 73280 & .391 \\ 6053 & 10 & 5257 & 52570 & .452 \\ 7646 & 13 & 6850 & 89050 & .557 \\ 9239 & 13 & 8443 & 109759 & .686 \\ 10832 & 4 & 10036 & 40140 & .733 \\ 12425 & 6 & 11629 & 69774 & .814 \\ 14018 & 2 & 13222 & 26444 & .845 \\ 15611 & 1 & 14815 & 14816 & .863 \\ 17204 & 2 & 16408 & 32816 & .901 \\ 18797 & 1 & 18001 & 18001 & .922 \\ 20390 & 0 & 19549 & 0 & .922 \\ 21983 & 0 & 21187 & 0 & .922 \\ 23576 & 1 & 22780 & 22780 & .949\end{array}$


RFP-1831 .

APPENDIX VI

B. $650^{\circ} \mathrm{C} / 4 \mathrm{HR}$ MICROSTRUCTURE. (continued)

\begin{tabular}{|c|c|c|}
\hline $\begin{array}{c}\text { Limit on Grain } \\
\text { Arca Class } \\
\text { Interval } \\
(\mu \mathrm{m})^{2}\end{array}$ & $\begin{array}{c}\text { Frequency } \\
\quad f_{i}\end{array}$ & $\begin{array}{l}\text { Mean Grain Area } \\
\text { per Class } \\
\text { Interval, } \mathbf{A}_{\mathfrak{i}} \\
(\mu \mathrm{m})^{2}\end{array}$ \\
\hline 25169 & 0 & 24373 \\
\hline 26762 & 0 & 25966 \\
\hline 28355 & 0 & 27559 \\
\hline 29948 & 0 & 29152 \\
\hline 31541 & 0 & 30745 \\
\hline 33134 & 0 & 32338 \\
\hline 34727 & 0 & 33931 \\
\hline 36320 & 0 & 35524 \\
\hline 37913 & 0 & 37117 \\
\hline 39506 & 0 & 38710 \\
\hline 41099 & 0 & 40303 \\
\hline 42692 & 0 & 41896 \\
\hline 44285 & 1 & 4'348y \\
\hline
\end{tabular}

Tot. Grain Area per Class Interval

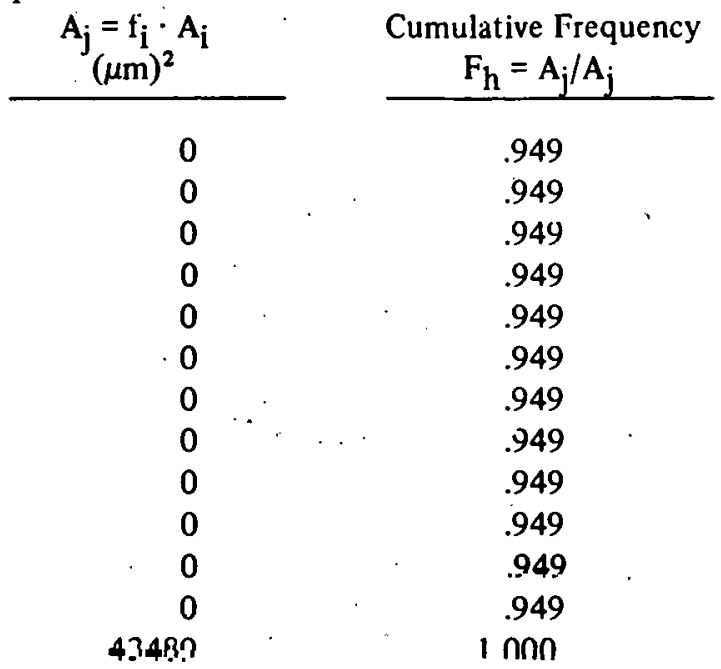

C. $700^{\circ} \mathrm{C} / 2 \mathrm{HR}$ MICROSTRUCTURE.

$\begin{array}{rrr}0.88 & 63 & 44 \\ 1325 & 187 & 707 \\ 2562 & 38 & 1944 \\ 3799 & 17 & 3181 \\ 5036 & 17 & 4418 \\ 62 / 3 & 8 & 5655 \\ 7510 & 5 & 6892 \\ 8747 & 4 & 8129 \\ 9984 & 5 & 9366 \\ 11221 & 4 & 10603 \\ 12458 & 2 & 11840 \\ 13695 & 2 & 13077 \\ 11932 & 2 & 14314 \\ 16169 & 0 & 15551 \\ 17406 & 1 & 16788 \\ 18643 & 2 & 18025 \\ 19880 & 0 & 19262 \\ 21117 & 0 & 20499 \\ 22354 & 0 & 21736 \\ 23591 & 1 & 22973 \\ 24828 & 0 & 24210 \\ 26065 & 1 & 25447 \\ 27302 & 0 & 26684 \\ 28539 & 0 & 27921 \\ 29776 & 0 & 29158 \\ 31013 & 0 & 30395 \\ 32250 & 1 & 31632\end{array}$

$\begin{array}{rc}2772 & 0.0037 \\ 132209 & .180 \\ 73872 & .278 \\ 54077 & .350 \\ 75106 & .450 \\ 45240 & .510 \\ 34460 & .556 \\ 32516 & .600 \\ 46830 & .662 \\ 42412 & .718 \\ 23680 & .750 \\ 26154 & .785 \\ 28628 & .823 \\ 0 & .823 \\ 16788 & .845 \\ 36050 & .893 \\ 0 & .893 \\ 0 & .893 \\ 0 & .893 \\ 22973 & .924 \\ 0 & .924 \\ 25447 & .958 \\ 0 & .958 \\ 0 & .958 \\ 0 & .958 \\ 0 & .958 \\ 31632 & 1.000\end{array}$

D. $775^{\circ} \mathrm{C} / 1 \mathrm{HR}$ MICROSTRUCTURE.
0- 176
224
88
19712
0.0256
676
204152
.291 
D. $775^{\circ} \mathrm{C} / 1 \mathrm{HR}$ MICROSTRUCTURE. (continued)

\begin{tabular}{|c|c|c|}
\hline $\begin{array}{l}\text { Limit on Grain } \\
\text { Area Class } \\
\text { Interval }^{*} \\
(\mu \mathrm{m})^{2}\end{array}$ & $\begin{array}{l}\text { Frequency } \\
\qquad f_{\mathfrak{i}}\end{array}$ & $\begin{array}{l}\text { Mean Grain Area } \\
\text { per Class } \\
\text { Interval, } A_{i} \\
(\mu \mathrm{m})^{2}\end{array}$ \\
\hline 2176 & 52 & 1676 \\
\hline 3176 & 21 & 2676 \\
\hline 4176 & 13 & 3676 \\
\hline 5176 & 8 & 4676 \\
\hline 6176 & 4 & 5676 \\
\hline 7176 & 4 & 6676 \\
\hline 8176 & 2 & 7676 \\
\hline 9176 & 1 & 8676 \\
\hline 10176 & 4 & 9676 \\
\hline 11176 & 2 & 10676 \\
\hline 12176 & 1 & 11676 \\
\hline 13176 & 2 & 12676 \\
\hline 14176 & 0 & 13676 \\
\hline 15176 & 4 & 14676 \\
\hline 16176 & 0 & 15676 \\
\hline 17176 & 0 & 16676 \\
\hline 18176 & 1 & .17676 \\
\hline 19176 & 0 & 18676 \\
\hline 20176 & 1 & 19676 \\
\hline 21176 & 0 & 20676 \\
\hline .22176 & 0 & 21676 \\
\hline 23176 & 1 & 22676 \\
\hline 24176 & 0 & 23676 \\
\hline 25176 & 0 & 24676 \\
\hline 26176 & 0 & 25676 \\
\hline 27176 & 0 & 26676 \\
\hline 28176 & 1 & 27676 \\
\hline
\end{tabular}

Tot. Grain Area per Class Interval

\begin{tabular}{rc}
$\begin{array}{c}A_{j}=f_{i} \cdot A_{i} \\
(\mu \mathrm{m})^{2}\end{array}$ & $\begin{array}{c}\text { Cumulative Frequency } \\
F_{h}=A_{j} / A_{j}\end{array}$ \\
\cline { 1 - 2 } 87152 & .404 \\
56196 & .477 \\
47788 & .539 \\
37408 & .588 \\
22704 & .618 \\
26704 & .652 \\
15352 & .672 \\
8676 & .684 \\
38704 & .734 \\
21352 & .762 \\
11676 & .777 \\
25352 & .810 \\
0 & .810 \\
58704 & .886 \\
0 & .886 \\
0 & .886 \\
17676 & .909 \\
0 & .909 \\
19676 & .935 \\
0 & .935 \\
0 & .935 \\
22676 & .964 \\
0 & .964 \\
0 & .964 \\
0 & .964 \\
0 & 1.000 \\
27676 &
\end{tabular}

E. $\quad 760^{\circ} \mathrm{C} / 6$ HR MICROSTRUCTURE.

$\begin{array}{rr}0-17 & 6 \\ 790 & 299 \\ 1563 & 101 \\ 2336 & 32 \\ 3109 & 29 \\ 3882 & 10 \\ 4655 & 6 \\ 5428 & 3 \\ 6201 & 2 \\ 6974 & 1 \\ 7747 & 5 \\ 8520 & 1 \\ 9293 & 1 \\ 10066 & 2 \\ 10839 & 1 \\ 11612 & 1 \\ 12385 & 0 \\ 13158 & 0\end{array}$

8.5
403.5
1176.5
1949.5
2722.5
3495.5
4268.5
5041.5
5814.5
6587.5
7360.5
8133.5
8906.5
9679.5
10452.5
11225.5
11998.5
12771.5

51
120646
118826
62384
78952
34955
25611
15124
11629
6588
36802
8131
8906
19359
10452
11226
0
0

0.0000579

.177

.356

.450

.567

.619

.657

.680

.697

.707

.762

.774

.787

.816

.831

.848

.848

.848 
E. $\quad 760^{\circ} \mathrm{C} / 6 \mathrm{HR}$ MICROSTRUCTURE. (continued)

$\begin{array}{ccc}\begin{array}{c}\text { Limit on Grain } \\ \text { Area Class } \\ \text { Interval* } \\ (\mu \mathrm{m})^{2}\end{array} & \begin{array}{c}\text { Frequency } \\ \mathrm{f}_{\mathrm{i}}\end{array} & \begin{array}{c}\text { Mean Grain Area } \\ \text { per Class } \\ \text { Interval, } A_{i} \\ (\mu \mathrm{m})^{2}\end{array} \\ 13931 & 1 & 13544.5 \\ 14704 & 1 & 14317.5 \\ 15477 & 0 & 15090.5 \\ 16250 & 0 & 15863.5 \\ 17023 & 1 & 16636.5 \\ 17796 & 1 & 17409.5 \\ 18569 & 0 & 18182.5 \\ 19342 & 0 & 18955.5 \\ 20115 & 1 & 19728.5 \\ 20888 & 1 & 20501.5\end{array}$

Tot. Grain Area per Class Interval

$\begin{array}{rc}\begin{array}{c}A_{j}=f_{i} \cdot A_{i} \\ (\mu \mathrm{m})^{2}\end{array} & \begin{array}{c}\text { Comulative Frequency } \\ F_{h}=A_{j} / A_{j}\end{array} \\ 13544 & .868 \\ 14318 & .889 \\ 0 & .889 \\ 0 & .889 \\ 16636 & .914 \\ 17410 & .940 \\ 0 & .940 \\ 0 & .940 \\ 19728 & .970 \\ 20502 & 1.000\end{array}$

* Class Intervals are centered about the mean grain area where $\mathbf{S} / 3$ was arbitrarily selected as the Class Interval. 


\section{APPENDIX VII}

\section{$\log _{e}$ (Grain Area) Histogram and Cumulative Frequency Distribution Data}

A. AS-ROLLED MICROSTRUCTURE.

Limit on $\log _{e}$
(Grain Area)
Class Interval*

1.63437

2.09826

.56215

3.02604

.48994

.95383

4.41772

.88162

5.34551

.80940

6.27329

.73719

7.20108

.66497

8.12886

.59276

9.05665

.52054

.98443

10.44833

.91222
Mean $\log _{\mathrm{e}}$

Frequency (Grain Area) per

Class Interval, $\mathbf{A}_{\mathbf{i}}$

1.86632

2.33020

.79410

3.25798

.72188

4.18516

.64966

5.11354

.57744

6.04132

.50522

.96910

7.43300

.89688

8.36078

.82466

9.28856

.75244

10.21634

.68022
Total

Class Interval Area . Cumulative Frequency

$\frac{\mathbf{A}_{\mathbf{j}}=\mathbf{f}_{\mathbf{i}} \cdot \mathbf{A}_{\mathbf{i}}}{\mathrm{l}}$

27.995

11.651

5.5882

39.096

66.994

41.858

106.94

189.20

178.48

320.19

299.24

313.61

401.38

323.77

259.18

150.02

204.35

107.28

81.731

21.360

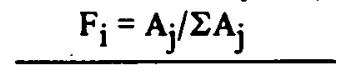

0.00889

.01269

.01436

.02677

.04804

.06133

.09528

.1553

.2120

.3137

.4087

.5082

.6356

.7384

.8207

.8683

.9332

.9672

.9932

1.0000

B. $650^{\circ} \mathrm{C} / 4 \mathrm{HR}$ MICROSTRUCTURE.

1.69978

2.13398

.56818

3.00238

.43658

.87080

4.30500

.73920

5.17340

.60760

6.04180

.47600

.91020

7.34440

.77860

8.21281

.64701

9.08121

.51542
1.91688

2.35108

.78528

3.21948

.65368

4.08788

.52208

.95628

5.39048

.82468

6.25888

.69308

7.12728

.56148

.99568

8.42988

.86408

9.29828
0.0000

9.5844

2.3511

52.920

3.2195

21.922

69.494

67.831

203.21

231.79

221.34

237.84

227.56

228.07

151.23

151.92

143.31

195.01

148.77
0.00000

.00393

.00490

.02661

.02792

.03691

.06542

.09324

.1766

.2716

.3624

.4600

.5533

.6469

.7090

.7712

.8300

.9100

.9710 
B. $650^{\circ} \mathrm{C} / 4 \mathrm{HR}$ MICROSTRUCTURE. (continued)

\begin{tabular}{|c|c|}
\hline $\begin{array}{c}\text { Limit on } \log _{e} \\
\text { (Grain Area) } \\
\text { Class Interval* }\end{array}$ & $\begin{array}{c}\text { Frequency } \\
f_{\mathfrak{i}}\end{array}$ \\
\hline .94962 & 4 \\
\hline 10.38382 & 1 \\
\hline .81802 & 1 \\
\hline 11.25223 & 1 \\
\hline
\end{tabular}

Mean $\log _{e}$

(Grain Area) per

Class Interval, $\mathbf{A}_{\mathbf{i}}$

.73248

10.16668

.60088

11.03508
Total

Class Interval Area

\begin{tabular}{c}
$A_{j}=f_{i} \cdot A_{i}$ \\
\hline 38.930 \\
10.167 \\
10.601 \\
11.035
\end{tabular}

Cumulative Frequency

$\mathrm{F}_{\mathrm{i}}=\mathrm{A}_{\mathrm{j}} / \Sigma \mathrm{A}_{\mathrm{j}}$
.9870
.9911
.9955
1.0000

C. $\quad 700^{\circ} \mathrm{C} / 2$ HR MICROSTRUCTURE.

$\begin{array}{rrr}1.45310 & & \\ .90611 & 5 & 1.67960 \\ 2.35911 & 0 & 2.13260 \\ .81211 & 3 & .58560 \\ 3.26511 & 21 & 3.03860 \\ .71812 & 10 & .49160 \\ 4.17112 & 17 & .94460 \\ .62412 & 18 & 4.39760 \\ 5.07712 & 26 & .85060 \\ .53013 & 23 & 5.30360 \\ .98313 & 32 & .75660 \\ 6.43613 & 39 & 6.20960 \\ .88914 & 36 & .66260 \\ 7.34214 & 29 & 7.11560 \\ .79514 & 26 & .56860 \\ 8.24814 & 19 & 8.02160 \\ .70114 & 21 & .47460 \\ 9.15415 & 16 & .92760 \\ .60715 & 12 & 9.38060 \\ 10.06015 & 5 . & .83360 \\ .51316 & .1 & 10.28660\end{array}$

8.3980
0.0000
7.7568
63.811
34.916
67.058
79.157
126.12
121.98
184.21
242.17
239.85
206.35
196.78
152.41
177.97
142.84
112.57
49.168
10.287

0.00000

.00378

.00378

.00726

.03596

.05166

.08181

.1174

.1741

.2290

.31181

.4207

.5286

.6214

.7098

.7784

.8584

.9226

.9733

.9954

1.0000

D. $775^{\circ} \mathrm{C} / 1$ HR MICROSTRUCTURE.

$\begin{array}{rrr}1.28936 & & \\ .68084 & 1 & 1.48510 \\ 2.07234 & 6 & .87659 \\ .46383 & 0 & 2.26809 \\ .85532 & 6 & .65958 \\ 3.24681 & 25 & 3.05106 \\ .63831 & 5 & .11256 \\ +.02980 & 19 & .83404 \\ .42129 & 14 & 4.22554 \\ .81273 & 35 & .61702 \\ 5.20428 & 46 & .00852 \\ .59577 & 53 & 5.40000 \\ .98726 & 54 & .79150 \\ 6.37880 & 55 & 6.18298 \\ .77025 & 38 & .57448 \\ 7.16174 & 37 & .96596 \\ .55323 & 30 & 7.35746\end{array}$

1.4851
11.260
0.0000
15.957
76.277
17.21 .3
72.847
59.157
161.60
230.39
286.20
312.74
340.06
249.83
257.74
220.72

0.000519

.00446

.00446

.01004

.03671

.04273

.06820

.08888

.1454

.2260

.3260

.4354

.5543

.6416

.7318

.8089 
D. $775^{\circ} \mathrm{C} / 1 \mathrm{HR}$ MICROSTRUCTURE: (continued)

\begin{tabular}{r}
$\begin{array}{c}\text { Limit on } \log _{e} \\
\text { (Grain Area) }\end{array}$ \\
Class Interval \\
\hline .94472 \\
8.33622 \\
.72771 \\
9.11920 \\
.51070 \\
.90219 \\
10.29368 \\
.68517 \\
11.07667
\end{tabular}

Mean $\log _{e}$ (Grain Area) per Frequency

$\mathrm{f}_{\mathbf{i}}$

19

16

6

6.

8

5

3

0

1
Class Interval, $\mathbf{A}_{\mathbf{i}}$

.74894

8.14044

.53192

.92341

9.31490

.70640

10.09792

.48938

.88087
Total

Class Interval Area

\begin{tabular}{c}
$A_{j}=f_{i} \cdot A_{i}$ \\
\hline 147.23 \\
130.25 \\
51.192 \\
53.540 \\
74.519 \\
48.532 \\
30.294 \\
0.0000 \\
10.880
\end{tabular}

Cumulative Frequency

\begin{tabular}{c}
$F_{i}=A_{j} / \Sigma A_{j}$ \\
\hline .8604 \\
.9060 \\
.9239 \\
.9426 \\
.9686 \\
.9856 \\
.9962 \\
.9962 \\
1.0000
\end{tabular}

E. $\quad 760^{\circ} \mathrm{C} / 6 \mathrm{HR}$ MICROSTRUCTURE.

$\begin{array}{rrrrr}1.78463 & & & & \\ 2.11333 & 2 & 1.94898 & 3.8980 & 0.00127 \\ 2.44202 & 0 & 2.27768 & 0.000 & .00127 \\ .77073 & 4 & .60638 & 10.426 & .00466 \\ 3.09942 & 0 & .93508 & 0.000 & .00466 \\ .42812 & 8 & 3.26378 & 26.11 & .01315 \\ .75682 & 5 & .59248 & 17.96 & .01900 \\ 4.08552 & 13 & .92118 & 50.98 & .03558 \\ .41421 & 7 & 4.24988 & 29.75 & .04526 \\ .74291 & 26 & .57858 & 119.04 & .08398 \\ 5.07160 & 27 & .90728 & 132.50 & .1271 \\ .40031 & 24 & 5.23598 & 125.66 & .1680 \\ .72900 & 68 & .56468 & 378.40 & .2911 \\ 6.05770 & 35 & .89338 & 206.27 & .3582 \\ .38640 & 41 & 6.22208 & 255.10 & .4412 \\ .71509 & 51 & .55078 & 334.09 & .5498 \\ 7.04379 & 67 & .87948 & 460.92 & .6998 \\ .37249 & 32 & 7.20818 & 230.66 & .7748 \\ .70119 & 25 & .53688 & 188.42 & .8361 \\ 8.02989 & 22 & .86558 & 173.04 & .8924 \\ .35858 & 14 & 8.19428 & 114.72 & .9297 \\ .68728 & 7 & .52298 & 59.661 & .9491 \\ 9.01598 & 7 & .85168 & 61.962 & .9693 \\ .34468 & 5 & 9.18038 & .9842 \\ .67337 & 5 & .50908 & 45.902 & .9904 \\ 10.00207 & 2 & .83778 & 19.018 & 1.0000\end{array}$

- Class intervals are centered about the mean $\log _{\theta}$ (Grain Area) where $S_{G} / 4$ was arbitrarily selected es the cless interval. 
